\title{
Nickel stress-tolerance in plant-bacterial associations
}

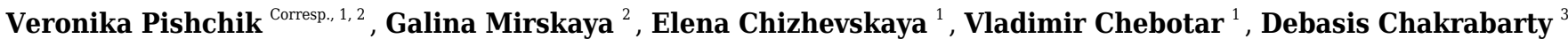 \\ 1 All-Russia Research Institute for Agricultural Microbiology, Saint-Petersburg- Pushkin, Russian Federation \\ 2 Agrophysical Scientific Research Institute, Saint Petersburg, Russian Federation \\ 3 CSIR-National Botanical Research Institute, Lucknow, India \\ Corresponding Author: Veronika Pishchik \\ Email address: veronika-bio@rambler.ru
}

Nickel (Ni) is an essential element for plant growth and is a constituent of several metalloenzymes, such as urease, Ni-Fe hydrogenase, Ni-superoxide dismutase. However, in high concentrations, $\mathrm{Ni}$ is toxic and hazardous to plants, humans and animals. High levels of Ni inhibit plant germination; reduce chlorophyll content, and cause osmotic imbalance and oxidative stress .Sustainable plant-bacterial native associations are formed under $\mathrm{Ni}$-stress, such as $\mathrm{Ni}$ - hyperaccumulator plants and rhizobacteria showed tolerance to high levels of $\mathrm{Ni}$. Both partners (plants and bacteria) are capable to reduce the $\mathrm{Ni}$ toxicity and developed different mechanisms and strategies which they manifest in plantbacterial associations. In addition to physical barriers, such as plants cell walls, thick cuticles and trichomes, which reduce the elevated levels of Ni entrance, plants are mitigating the Ni toxicity using their own antioxidant defense mechanisms including enzymes and other antioxidants. Bacteria in its turn effectively protect plants from $\mathrm{Ni}$ stress and can be used in phytoremediation. PGPR (plant growth promotion rhizobacteria) possess various mechanisms of biological protection of plants at both whole population and single cell levels. In this review, we highlighted the current understanding of the bacterial induced protective mechanisms in plant-bacterial associations under Ni stress. 


\section{Nickel stress-tolerance in plant -bacterial associations}

2 Veronika Pishchik $^{1,2}$, Galina Mirskaya ${ }^{2}$, Elena Chizhevskaya ${ }^{1}$, Vladimir Chebotar ${ }^{1}$, Debasis

3 Chakrabarty $^{3}$

4 1 All- Russia Research Institute for Agricultural Microbiology, sh. Podbelskogo, 3, Saint-

5 Petersburg- Pushkin, 196608, Russia

$6{ }^{2}$ Agrophysical Scientific Research Institute, Grazhdansky pr. 14, Saint-Petersburg, 195220,

7 Russia

$8{ }^{3}$ CSIR-National Botanical Research Institute, Rana Pratap Marg, Lucknow-22600, India

9 Corresponding Author:

10 Veronika N. Pishchik ${ }^{1}$

11 Email address: veronika-bio@rambler.ru

\section{Abstract}

Nickel (Ni) is an essential element for plant growth and is a constituent of several metalloenzymes, such as urease, Ni-Fe hydrogenase, Ni-superoxide dismutase. However, in high concentrations, $\mathrm{Ni}$ is toxic and hazardous to plants, humans and animals. High levels of Ni inhibit plant germination; reduce chlorophyll content, and cause osmotic imbalance and oxidative stress. Sustainable plant-bacterial native associations are formed under Ni-stress, such as Ni hyperaccumulator plants and rhizobacteria showed tolerance to high levels of Ni. Both partners (plants and bacteria) are capable to reduce the Ni toxicity and developed different mechanisms and strategies which they manifest in plant-bacterial associations. In addition to physical barriers, such as plants cell walls, thick cuticles and trichomes, which reduce the elevated levels of Ni entrance, plants are mitigating the Ni toxicity using their own antioxidant defense mechanisms including enzymes and other antioxidants. Bacteria in its turn effectively protect plants from $\mathrm{Ni}$ stress and can be used in phytoremediation. PGPR (plant growth promotion rhizobacteria) possess various mechanisms of biological protection of plants at both whole population and single cell levels. In this review, we highlighted the current understanding of the bacterial induced protective mechanisms in plant-bacterial associations under Ni stress.

\section{Introduction}


31 Heavy metals (HM) contaminant of agricultural land and water causes major environmental and 32 human health problems (Roy \& McDonald, 2015; Ihedioha, Ukoha \& Ekere, 2017). Nickel (Ni)

33 has been indicated as one of the most dangerous HM for the environment, and Ni affected plants 34 undergo a severe stress condition (Hussain et al., 2013; Pietrini et al., 2015).

$35 \mathrm{Ni}$ enters the soil through a variety of sources such as metal smelters, industrial effluents, Ni36 oxide nanoparticles during the manufacture of electronic devices and catalysts, wastewater, 37 including uses of fertilizers and pesticides (Song et al., 2008; Cabanillas et al., 2012). Among 38 heavy metals, $\mathrm{Ni}$ is characterized by barrier-free penetration into the aboveground organs of 39 plants (Fabiano et al., 2015; Deng et al., 2018). Ni induces cytotoxic and genotoxic effects on 40 plants (Magaye \& Zhao, 2012; Mana \& Bandyopadhyay, 2017). Excessive accumulation of Ni in 41 plants leads to oxidative stress, accompanied by an increase in the accumulation of ROS 42 (reactive oxygen species) (Sharma \& Dietz, 2009), an inhibitor of growth, mineral nutrition 43 (Parida, Chhibba \& Nayyar, 2003), photosynthesis (Prasad, Dwivedi \& Zeeshan, 2005), 44 membrane functions, carbohydrate metabolism (Seregin \& Kozhevnikova, 2006) and water 45 regime of plants (Llamas \& Sanz, 2008).

46 Plants have a number of potential mechanisms to protect against high concentrations of heavy 47 metals, with which they manage to survive under metal stress (Schützendübel \& Polle, 2002). 48 Resistance to heavy metal toxicity depends on reduced absorption, increased in vacuolar 49 sequestration and enhanced expression of defense proteins. There are some recent reviews about 50 strategies adapted by plants to neutralize and overcome the Ni stress (Fabiano et al., 2015; 51 Sachan \& Lal, 2017; Shahzad et al., 2018a; Deng et al., 2018) that indicate a great interest 52 among scientific community.

53 PGPR (Plant Growth Promotion Rhizobacteria), inhabiting plant rhizosphere and rhizoplane and 54 interacting with root exudates and soil microbial communities, form strong associations with 55 plants (Brencic \& Winans, 2005). PGPR in native ecosystems play a key role in protecting plants 56 from various stress factors, including high concentrations of HM. Under HM stress sustainable 57 plant-microbial associations are formed for the joint survival of both partners (Jing, He \& Jing, 58 2007). Such plant- bacterial associations were described for plants - Ni-hyperaccumulators 59 Alyssum bertolonii (Mengoni et al., 2001) and Tlaspi goesingense (Idris et al., 2004)with their 60 Ni-resistant dominant bacteria from genera Pseudomonas, Methylobacterium, Rhodococcus and 61 Okibacterium .Also, such associations are artificially formed when PGPR are used for 
62 phytoremediation, the success of which depends on the correctly used association. Endophytic

63 bacteria penetrate into the root cortex, live inside the plant roots in the root cells, improved

64 nutrient uptake and plant growth. Endophytic bacteria are also successfully used for

65 phytoremediation (Jan et al., 2019, Naveed et al, 2020). Phytoremediation is a green strategy that

66 uses hyper-accumulator plants and their rhizospheric microorganisms to stabilize, transfer or

67 degrade pollutants in soil, water and environment. This technology is considered as well-

68 efficient, cheap and adaptable with the environment (Nedjimi, 2021).

69 This review focuses on plant defense mechanisms in plant -bacterial associations under Ni 70 stress. Previous reviews touched this topic a little (Pishchik et al., 2016; Egamberdieva, Abd71 Allah \& da Silva, 2016), focusing mainly on other heavy metals, specifically on $\mathrm{Pb}, \mathrm{Cd}$, and $\mathrm{Zn}$.

72

\section{Survey methodology}

74

Initially we analyzed the closed-relation reviews to our topic, to choose the general direction and novelties of our review. The key words for each section of review were selected and used in search of Web of Science and Google Scholar databases. To collect all relevant information we used the following keyword combinations: nickel (Ni) contamination and soil; Ni stress and plants; Ni and physiological destructions in plants; Ni stress and plant antioxidant enzymes; Ni and phytochelatins, $\mathrm{Ni}$ and metallothioneins; $\mathrm{Ni}$ and proline; $\mathrm{Ni}$ and salicylic acid; $\mathrm{Ni}$ and phytohormones; Ni- stress and plant genes; Ni-stress and bacterial genes; Ni- stress and microbial community; Ni- stress and PGPR; Ni-stress and endophytic bacteria Ni stress and plant - bacterial association; Ni and bioremediation. The abstracts of selected papers were initially screened according to plan of our review, which were focused on topics of survival of plantbacterial systems under Ni stress. We have mostly focused on the papers of 2000-2020, since the main research in this area were done at this time.

\section{$\mathrm{Ni}$ in soil, in plants and in bacterial cells}

The contamination of soil with $\mathrm{Ni}$ and other HM resulting due to wastes from heavy industry and nonferrous metallurgy is a major environmental concern. However, Ni can be introduced into the environment with mineral fertilizers, waste water, sludge, oil spills and household rubbish

(Ghosh \& Singh, 2005; Kozlov, 2005; Vodyanitsky, 2011). The worldwide average 
92 concentration of $\mathrm{Ni}$ in natural soils is $22 \mathrm{mg} \mathrm{kg}^{-1}$ (Kabata-Pendias, 2000). The range of nickel 93 (Ni) concentrations may reach $200-26,000 \mathrm{mg} \mathrm{kg}^{-1}$ in polluted soils, as compared with natural 94 soils (10-1000 $\left.\mathrm{mg} \mathrm{kg}^{-1}\right)$ (Sreekanth et al., 2013; Yusuf et al., 2011). The maximum recorded 95 nickel concentration in contaminated soils was observed in Canada and reached 26,000 mg kg-1 96 (Kabata-Pendias, Mukherjee \& Arun, 2007). The content of Ni in polluted soils of the city 97 exceeds Tentative Permissible Concentrations level by 10-86 folds (Vodyanitskii et al., 2011) 98 and 75 times higher with severe pollution compared to background (Evdokimova, Kalabin \& 99 Mozgova, 2011).

$100 \mathrm{Ni}$ is the main pollutant of farmlands in south and central China (Rizwan et al., 2017), the Ni 101 concentrations in China soils may increase in 6.5 times compared to background (Ding et al., 102 2008). Soils of agricultural land near industrial areas in India contain 47 to $178 \mathrm{mg} \mathrm{kg}^{-1} \mathrm{Ni}$ 103 (Rajindiran et al., 2015). In this regard, the problem of the accumulation of excess Ni in 104 agricultural products arises.

$105 \mathrm{Ni}$ is an essential trace element (in low concentrations $0.01-5 \mu \mathrm{g} / \mathrm{g}$ dry weight) for plants. Ni (II) 106 is a functional component in urease (Gerendas, Zhu \& Sattelmacher, 1998), glyoxalases, peptide 107 deformylases, methyl Co-M reductases, hydrogenases and superoxide dismutases (Aziz, Gad \& 108 Badran, 2007). However the high level of $\mathrm{Ni}$ concentrations (more than $10^{-4} \mathrm{M} / \mathrm{l}$ ) can lead to 109 toxicity symptoms and growth inhibition in most plants (Hall, 2002). The average Ni content in 110 wheat leaves (plant-excluder, accumulates metals in roots) is $0.34 \mathrm{mg} \mathrm{kg}^{-1}$ (Kabata-Pendias, 111 Mukherjee \& Arun, 2007). The family Brassicaceae has the highest number of hyper 112 accumulator plants (Reeves \& Baker, 2000). Such representatives of the family as Alyssum 113 caricum (Dudley) and Thlaspi oxyceras (Boiss.) can accumulate significant amounts of Ni (up to 11412273 and $13778 \mathrm{mg} / \mathrm{kg}$, respectively) in the leaves (Shahzad et al., 2018a).

$115 \mathrm{Ni}$ is an essential component of bacterial enzymes which catalyze metabolic reactions with 116 molecular hydrogen, nitrogen, carbon monoxide and carbon dioxide and is involved in 117 pathogenesis and detoxifications processes (Mulrooney \& Hausinger, 2003). However, influence 118 of high concentrations of $\mathrm{Ni}$ in bacterial cells leads to oxidative stress resulting in damage of 119 nucleic acids, lipid peroxidations, and enzymes inactivation (Eitinger et al., 2005).

120 
122 Metal toxicity leads to molecular changes in plants such as: (a) formation of reactive oxygen

123 species (ROS) by auto-oxidation and Fenton reaction (Noctor, Reichhel \& Foyer, 2018); (b)

124 locking of main functional groups in biomolecules; (c) expulsion of main metal ions from

125 biomolecules (Gajewska \& Skłodowska, 2007). Ni ions in high concentrations have a destructive

126 effect on growth, mineral nutrition, photosynthesis (Zaid et al., 2019) carbohydrate transport and

127 water relations (Seregin \& Kozhevnikova, 2006). The increasing levels of Ni stress enhanced

128 methylglyoxal, electrolyte leakage, hydrogen peroxide, and lipid peroxidation content in plants

129 (Zaid et al., 2019). Ni decreases seed germination and seedling growth due to change in the 130 activity of hydrolytic enzymes, followed by a delay in the transportation of mobilized reserves

131 from endosperm to the embryonic axis (Ashraf et al., 2011). Ni may disrupt the membrane 132 stability (Shahzad et al, 2018a) by reducing the uptake of Ca and Zn (Taiz \& Zeiger, 2006). High 133 concentration of $\mathrm{Ni}$ in plants leads to mitotic abnormalities, chromosomal aberrations and 134 decrease in the rate of cell stretching (Sreekanth et al., 2013; Manna \& Bandyopadhyay, 2017).

135 It has been reported that $\mathrm{Ni}$ stress can reduce cytosine methylation levels in clover and hemp and 136 the decrease in methylation depends upon the dosage of the heavy-metal stress. Methylation137 sensitive amplification polymorphism (MSAP) data shows that the methylation patterns of 138 different plants within the CCGG sites are similar before and after HM stress, suggesting that the 139 stress-induced changes in methylation are not distributed randomly (Aina et al., 2004).

140 The differential regulation of chloroplastic heat shock protein (Cp-sHSPs or HSP26.13p) in 141 Chenopodium album protects the plant both from heat and $\mathrm{Ni}$ as well as other $(\mathrm{Cu}$ and $\mathrm{Cd}) \mathrm{HM}$ 142 stresses (Haq et al., 2013). It was revealed in proteome analysis of different plant species that 143 ubiquitin activity can be reduced significantly by $\mathrm{Ni}$ and other $\mathrm{HM}(\mathrm{Cd}, \mathrm{Pb}, \mathrm{Co}, \mathrm{Cu}, \mathrm{Cr}, \mathrm{Hg})$ at $144100 \mu \mathrm{M}$ concentration, whereas low concentrations can induce $26 \mathrm{~S}$ proteasome activity. Although 145 these metals induce the accumulation of ubiquitin conjugated proteins, the abundance of $20 \mathrm{~S}$ 146 core protein in UPS system is not changed (Aina et al., 2007; Pena et al., 2008).

\section{Plants defense system}

148 Plants have different levels of protection against elevated levels of HM. The first level is the 149 physical barrier, represented by various morphological structures, such as a thick cuticle, cell 150 walls, trichomes (Hall, 2002; Fourati et al., 2016). Trichomes can secrete various secondary 151 metabolites to detoxify heavy metals (Hauser, 2014). High concentrations of Ni absorbed into 152 the vacuole, which protects the cytoplasm from the toxic effect (Krämer et al., 2000). The 
153 sequestration of $\mathrm{Ni}$ into the leaf vacuole can be connected with a vacuolar metal-ion transporter 154 protein (TgMTP1) (Persans, Nieman \& Salt, 2001). The second level of biochemical protection 155 is the inclusion of heavy metals into plant tissue. In this case, the plant synthesizes various 156 substances of an enzymatic and non-enzymatic nature (Manoj et al., 2020). The response of 157 plants to Ni stress depends on the plant species. At the same time, intraspecific and interspecific 158 hybrid differences in the presence of $\mathrm{Ni}$ in high concentrations are noted (Amjad, 2020a; Amjad 159 et al., 2020b).

160 Under stress of high Ni concentrations, plants trigger numerous adaptive mechanisms to 161 neutralize its action, including the induction of many low molecular weight protein chelators, 162 such as phytochelatins and metallothioneins, specific amino acids, such as proline, and activation 163 of antioxidant enzymes (Dalvi \& Bhalerao, 2013; Viehweger, 2014). The equilibrium between 164 the synthesis and detoxification of free radicals in plants is supported by plant enzymes and 165 antioxidants of nonenzymatic nature, such as ascorbate, glutathione, tocopherol, carotenoids and 166 phenols (Mittler et al., 2004).

167 Glutathione (GSH) plays a significant role in cellular redox balance by binding to Ni and other 168 HM. It was found that elevated GSH concentration driven by constitutively elevated SAT (serine 169 acetyltransferase activity) correlated with increased resistance to Ni stress in Thlaspi goesingense 170 (Freeman et al., 2004). Besides, it was shown that plants resistance to HM is clearly linked to the 171 efficiency of glutathione S-transferases (GST) in the detoxification process (Wu et al., 2019). So, 172 for $\mathrm{Ni}$ it a negative correlation between GST/peroxydase activities and chlorophyll (Chl) content 173 has been indicated (Helaoui et al., 2020).

174 Plants synthesize proline in response to nickel stress. That was shown for various plant species, 175 such as Triticum aestivum (Gajewska \& Skłodowska, 2009), Brassica oleracea var. capitata 176 (Pandey \& Sharma, 2002), Pisum sativum (Gajewska \& Skłodowska, 2005). Proline functioning 177 as osmolyte is also a defense against Ni toxicity (Seregin \& Kozhevnikova, 2006).

178 Proline level was higher in Ni-treated rice plants compared to Cd-treated plants. However, Ni 179 cations in a high concentration $(1.0 \mathrm{mM})$ significantly decreased proline synthesis (Jan et al., 180 2019). 
181 Plants can decrease Ni toxicity, chelating Ni cations with various organic acids. Malic acid 182 synthesis is associated with Ni tolerance in plants such as Ni-hiperaccumulator Stackhousia 183 tryonii Bailey (Bhatia, et al., 2005), ryegrass, and maize (Yang et al., 1997).

184 Ni-tolerance of the eight different species (Homalium kanaliense (Vieill.) Briq., Casearia silvana 185 Schltr, Geissoishirsuta Brongn. \& Gris, Hybanthus austrocaledonicus Seem, Pycnandra 186 acuminata (Pierre ex Baill.) Swenson \& Munzinger (syn Sebertia acuminata Pierre ex Baill.), 187 Geissois pruinosa Brongn \& Gris, Homalium deplanchei (Viell) Warb. and Geissois bradfordii 188 (H.C. Hopkins) was associated with citric acid (Callahan et al., 2012).

189 Antioxidant enzymes. The antioxidant enzymes: superoxide dismutase (SOD), catalase (CAT), 190 glutathione peroxidase (GSH-Px), guaiacol peroxidase(GPX), peroxiredoxins (Prxs) and enzymes 191 of the ascorbate-glutathione (AsAGSH) cycle, such as ascorbate peroxidase (APX), 192 monodehydroascorbatereductase (MDHAR), dehydroascorbatereductase (DHAR), and 193 glutathione reductase (GR) are indicative enzymes for a high level of abiotic stress in plants 194 (Mittler et al., 2004).

195 The effect of Ni on antioxidant enzymes is different for different types of plants. Pandey \& 196 Sharma (2002) reported that Ni reduced CAT and POD activities in cabbage leaves. However in 197 pigeon pea (Cajanu scajan L.) there was no change in CAT activity under Ni stress, while SOD, 198 glutathione reductase (GR) and POD activities were increased (Rao \& Sresty, 2000). Ni stress 199 significantly decreased activities of CAT and SOD and increased activities of glutathione 200 peroxidase (GSH-Px) in wheat plants (Gajewska et al, 2006; Gajewska \& Sklodowska, 2007). In 201 shoots of Ni-stressed Solanum nigrum L., an enhanced activity of SOD and APX, accompanied 202 by a decline of CAT activity were observed. In roots, increases in SOD and CAT activities were 203 detected in response to Ni, whilst APX was not increased (Soares at al., 2016).

204 Data on plants antioxidant activities are summarized in Table1. Since various actions of Ni on 205 plant antioxidant enzymes are described, further study of this direction is necessary.

206 Phytochelatines (PCs) are the most important metal-binding ligands, since it is believed that the 207 synthesis of these compounds is one of the key detoxification mechanisms (Chen et al., 2008). 208 PCs are low molecular weight, short-chain thiol repeating proteins that have high affinity for 209 binding to HMs when they are at toxic levels (Lee et al., 2002; Chen et al., 2008; Shukla et al., 210 2013). PCs are produced in plants from sulfur-rich glutathione (GSH) using 
211 phytochelatinsynthase (PCS). PCs form high-molecular complexes with toxic metals, including $212 \mathrm{Ni}$, in the cytosol and subsequently transfer them to plant vacuoles (Song et al., 2014). Induction 213 of PCs synthesis occurs within cells as a result of exposure to various levels of Ni in both the 214 roots and above-ground organs. Nickel accumulation resulted in formation of PCs in Nicotiana 215 tabacum L and Thlaspi japonicum (Nakazawa et al., 2001; Mizuno et al., 2003).

216 PCs' synthesis is considered as one of the protective functions of plants against the stress of 217 nickel and other metals (Talebi et al., 2019).It has been suggested, that PCs may serve as a 218 biological marker for $\mathrm{Ni}$ accumulation in plants (Ameen et al., 2019). That suggestion is 219 confirmed in the study of phytochelatins gene expression in response to the action of different 220 concentrations of nickel in alfalfa plants (Helaoui et al., 2020).

221 Though Ni was a relatively effective activator of PC synthase during in vitro studies, a 222 functioning more effective and alternative detoxification mechanisms, such as metallothioneins 223 and histidine in plants was proposed (Cobbett, 2000).

224 Metallothioneins (MTs) are low molecular weight cysteine-rich proteins (4-8 kDa) that make 225 up an extremely heterogeneous family of metal-binding proteins that are ubiquitous in cells 226 (Peroza \& Freisinger, 2007). In plants, MTs are involved in neutralizing HM toxicity through 227 cell sequestration, homeostasis of intracellular metal ions, and regulation of metal transport (Guo 228 et al., 2013). MTs form metal-thiolate complexes; therefore, they can tolerate to elevated 229 concentrations of metals (Kumar et al., 2012; Mirza et al., 2014).

230 Ni increases the MTs expressions in Solanum nigrum (Ferraz et al., 2012) and Lupinus luteus 231 (Jaskulak et al., 2019), that results prove the involvement of MTs in Ni homeostasis and 232 detoxification.

233 It is shown that MTs genes can be used to create HM-resistant plant-microbial systems and their 234 subsequent application in phytoremediation or phytostabilization technologies (Pérez-Palacios et 235 al., 2017; Tsyganov et al., 2020).

236 Phytohormones are classified into different groups (auxins, cytokinins, gibberellins, 237 brassinosteroids, salicylic acid, abscisic acid, and jasmonates) and plays different roles in plant 238 growth and development.

239 A positive non-significant effect of combined application of gibberellins and cytokinins effect on 240 Ni phytoextraction efficiency of Alyssum corsicum was demonstrated (Cabello-Conejo et al., 
241 2013). Auxins were found as the most effective phytohormones for increasing $\mathrm{Ni}$ yield from $\mathrm{Ni}$

242 hyperaccumulating Alissum and Noccaea species. All the phytohormones increased plants

243 biomass, but not in all cases the increase in biomass was associated with an increase in nickel

244 yield (Cabello-Conejo, Prieto-Fernández \& Kidd, 2014).

245 As it was found that application of gibberellins, cytokinins and auxins generally led to a 246 reduction in shoot Ni concentration of Alissum and Noccaea species (Cabello-Conejo, Prieto-

247 Fernández \& Kidd, 2014).

248 The application of epibrassinolide (EBL) recovered the growth Brassica juncea and reduced $\mathrm{Ni}$ 249 uptake in roots and shoots and improved activities of SOD, CAT, APOX and POD (Kanvar et 250 al., 2013), as well as photosynthetic pigments, osmolyte accumulation in Solanum nigrum 251 (Soares et al., 2016). Application of EBL under Ni stress helps to obtain large plant biomass but 252 possible mechanism of epibrassinolide is still poorly understood (Shahzad et al., 2018b).

253 Abscisic acid (ABA) induces ethylene biosynthesis in adult plants and promotes their senescence 254 and abscission (Liu et al., 2016).Under stress conditions, ABA signaling interacts with plants 255 gibberellin and auxin signaling pathways and controls lateral root development (Zhao et al., 256 2014). Ni stress in rice increased the ABA level and ABA was increased with increased heavy 257 metal concentration (Janet al., 2019). Opposite, concentration of salicylic acid (SA) decreased 258 significantly under HM stress, which confirmed the antagonistic effect between SA and ABA 259 (Jan, 2019).

260 SA is plant phenolic, and is present in plants as a free and conjugated form (Maruri-López et al., 261 2019). SA can alleviate HM toxicity, decrease ROS, protect membrane stability, interact with 262 other plant hormones, up-regulate hemeoxygenase, improve the performance of the 263 photosynthetic machinery (Sharma et al., 2020). SA plays a key role in the regulation of plant 264 growth, development, in defense from HM stress and in plant responses (Freeman et al., 2005; 265 Pasternak et al., 2019). It is known, that GSH- Glutathione mediated Ni tolerance mechanism in 266 Thlaspi hyperaccumulators is signaled by the constitutively elevated levels of salicylic acid (SA) 267 (Freeman et al., 2005). SA alleviates metal toxicity influencing their uptake and accumulation in 268 plant organs (Dalvi, Bhalerao, 2013). Application of SA under Ni-stress reduced $\mathrm{ROS}, \mathrm{H}_{2} \mathrm{O}_{2}$ 269 and MDA contents and lipoxygenase activity, thus up-regulating the capacity of antioxidant 270 defense system in chloroplasts of maize (Wang et al., 2009) and wheat (Siddiqui et al., 2013), 
271 accelerated the restoration of growth processes and improves the total alkaloid content in

272 periwinkle (Catharanthus roseus L.) (Idrees etal., 2013).

273 The role of phytohormones in HM stress is discussed in scientific literature but the effects of

274 phytohormones on plants differ and depend on the application rates and time, as well as on the

275 environmental factors and plant species.

276

\section{Genes involved in plant protection system to Ni stress}

278 Ni uptake by plant roots can be connected with Fe transporter(s). For instance, in the Ni

279 hyperaccumulator Alyssum inflatum, Fe accumulation in roots was stimulated by increased $\mathrm{Ni}$

280 concentrations (Ghasemi, Ghaderian \& Krämer, 2009) because of the lack of substrate specificity

281 of AtIRT1. Ni cations could be absorbed via the ferrous transporter IRT1 in A. thaliana (Nishida

282 et al., 2011; Nishida, Aisu \& Mizuno, 2012).

283 No specific Ni efflux transporter has been identified. When getting into xylem vessels, Ni

284 transport is mainly driven by leaf transpiration (Centofanti et al., 2012). Ni absorption by leaf

285 cells may involve transporters from the ZIP family (ZNT1 and ZNT2), as the gene expression of

286 these transporters triggered under Ni stress (Visioli, Gulli \& Marmiroli, 2014).

287 Based on recent genetic studies, the following genes were proposed as candidates for Ni-stress in 288 different plant defense system: serine acetyltransferase (SAT), glutathione reductase (GR) in 289 Thlaspi goesingense (Freeman et al., 2004), glutathione S-transferase in Betula papyrifera 290 (Theriault, Michael \& Nkongolo, 2016), 1-aminocyclopropane-1-carboxylic acid deaminase 291 (ACC) in Brassica napus (Stearns et al., 2005) and in Quercusrubra (Djeukam \& Nkongolo, 292 2018), nicotianamine synthase (NAS3) in Thlaspi caerulescences (Mari et al., 2006) and Populus 293 tremuloides (Czajka et al., 2018), thioredoxin family protein in Chlamydomonas reinhardtii 294 (Lemaire et al., 2004) and in Betula papyrifera (Theriault, Michael \& Nkongolo, 2016)

295 In recent years, the search for genes responsible for plant resistance to nickel stress became one 296 of the important areas. Several candidate genes that are involved in plant protection against Ni 297 stress have been identified. However, work in this direction should be continued.

298 There are also very few works concerning the study of the level of expression of plant genes 299 under nickel stress. The main nickel resistance mechanism in Betula papyrifera is a

300 downregulation of genes associated with translation (in ribosome), binding, and transporter 
301 activities (Theriault, Michael \& Nkongolo, 2016). Four nicotianamine synthase genes in

302 Arabidopsis were upregulated under Ni stress (Kim et al., 2005). GS and GOGAT activities were 303 inhibited and the expression levels of their associated genes (OsGS2, OsFd-GOGAT and

304 OsNADH-GOGAT) were downregulated in response to Ni stress.

305 It is known, that microRNAs in plants involved in the post-transcriptional regulation of genes

306 expression and are critical regulators of HM stress (Dubey et al., 2018). So miR838 was found as 307 the most responsive to the Ni- stress in Ricinus communis L (Celik \& Akdaş, 2019). However, 308 the role of microRNAs in Ni stress is poorly understood and new information to explore their 309 role is necessary.

310

\section{Bacterial genes involved in Ni stress}

312 Ni uptake by microorganisms is regulated by secondary transporters and by ATP-binding 313 cassette (ABC) systems (Eitinger \& Mandrand-Berthelot, 2000; Mulrooney \& Hausinger, 2003; 314 Maitra, 2016). The secondary systems - nickel/cobalt transporters (NiCoTs; TC 2.A.52.) are 315 widely distributed in bacteria as well as in some archaea and fungi (Eitinger et al., 2005). The 316 best investigated ABC-type Ni permease is NikABCDE system of E. coli, composed of a 317 periplasmic binding protein (NikA), two integral membrane proteins (NikBC) and two ABC proteins (NikDE). In E. coli, Ni overstress is avoided via the repressor NikR, which binds to the promoter region of the nikABCDE operon when Ni is present (De Pina et al., 1999; Chivers \& Sauer, 2000). NikR has both strong (in the pM range) and weak (nM) Ni-binding sites, allowing

322 (Bloom \& Zamble, 2004; Maitra, 2016).

323

324

325 326

327 328
HupE/UreJ and UreH are two other families of suspected secondary metal carriers that are distantly related to NiCoTs (Eitinger et al., 2005). HupE/UreJ proteins are common among bacteria and encoded within certain hydrogenase [NiFe] or urease gene clusters (McMillan, Mau \& Walker,1998; Baginsky et al., 2004). Gene ureH was found in the urease operon in thermophilic bacteria (Maeda et al., 1994). These genes have similar sites to NiCoTs and presumably participate in Ni transport.

Often bacterial nickel resistance is plasmid mediated. For example, in resistant to heavy metals bacteria Cupriavidus metallidurans CH34 harbors plasmid pMOL28 which is responsible for Ni, $\mathrm{Hg}$ and $\mathrm{Cr}$ resistance (Nies et al., 1989; Mergeay, 1995). Ni efflux driven by a RND transporter

Peer] reviewing PDF | (2020:10:53459:1:1:NEW 18 Jun 2021) 
332 is the basis of resistance in this strain. Two operon systems have been studied, a nickel-cobalt

333 resistance $\mathrm{Cnr}$ ( $c n r \mathrm{CBA}$ are structural resistance genes with $c n r \mathrm{YXH}$ regulatory genes)

334 (Liesegang et al., 1993) and a Ni-Co-Cd resistance, Ncc (Ncc CBA operon) (Schmidt \&

335 Schlegel, 1989). The atmA gene (encodes ABC-transporter) was also found in the genome,

336 which increases $\mathrm{Ni}$ and Co resistance in both C. metallidurans and E. coli and probably works

337 together with other resistance operons (Mikolay \& Nies, 2009).

338 Two distinct Ni resistance loci ( $n c c$ and $n r e$ ) were found on plasmid pTOM9 from

339 Achromobacter xylosoxidans $31 \mathrm{~A}$. Expression of the nreB gene was specifically induced by $\mathrm{Ni}$

340 and conferred Ni resistance on both A. xylosoxidans 31A and E. coli (Grass et al., 2001). Other

341 resistant gene in E.coli is the $r c n \mathrm{~A}(y o h \mathrm{M})$ gene responsible for $\mathrm{Ni}$ and Co efflux (Rodrigue,

342 Effantin \& Berthelot, 2005). In the unicellular cyanobacterium Synechocystis sp. PCC 6803 and

343 Helicobacter pylori, a Ni resistance operon $n r s$ and czn operon ( $\mathrm{Cd}, \mathrm{Zn}$ and Ni resistance) had

344 been described respectively (García-Domínguez et al., 2000, Stahler et al., 2006). NrsB and

345 Nrs A proteins are homologues to $\mathrm{CzcB}$ and $\mathrm{CzcA}$ and they probably form a membrane-bound

346 protein complex catalyzing Ni efflux by a proton/cation antiport.

347 Although bacterial genes involved in the transfer and accumulation of nickel have been studied,

348 some questions remain unclear. For example, there is very little information on the genetic

349 regulation in plant-bacterial associations. Plant-associated bacteria probably have a different

350 genes enabling adaptation to the plant environment. The research in this direction is just

351 emerging.

352

353 Plant - bacterial associations

354 The rich diversity of root exudates and plant rhizodeposits attract diverse and unique microbial 355 communities (Brencic \& Winans, 2005, Chaparro et al., 2012). In plant-microbial associations,

356 the host plant and associated microorganisms form a multicomponent integral system with new

357 properties determined by the interaction of partners. Rhizobacteria can modulate their

358 metabolism depending on the composition of root exudates towards optimizing nutrient

359 acquisition (Hardoim, Van Overbeek \& Van Elsas 2008, Liu et al., 2019).

360 Root exudates and signal compounds that regulate the structure and diversity of the rhizosphere

361 and rhizoplane microbial communities, and indirectly regulate the fluxes of biologically active 
362 substances synthesized by microorganisms (Bais et al., 2006, Smith, Gravel \&Yergeau, 2017).

363 Therefore plants can modulate its microflora by dynamically adapting it to the environment

364 (Vandenkoornhuyse et al., 2015, Liu et al, 2019)

365 In its turn, rhizobacteria can modulate their metabolism depending on the composition of root 366 exudates towards optimizing nutrient acquisition (Hardoim, Van Overbeek \& Van Elsas 2008).

367 PGPR also can absorb ACC excreted from the plants and hydrolyzed by the ACC deaminase 368 decreasing the content of ACC from the environment and consequently reduce stress ethylene 369 level (Glick, 2005).

370 It was found, that Pseudomonas putida, Pseudomonas fluorescens can inhabit not only in soil,

371 but on plant leaves and roots and form biofilms (Ude et al, 2006). The formation of the biofilm is 372 influenced by the quorum-sensing (QS) process (Fuqua \& Greenberg, 2002). The mechanisms of 373 quorum formation are described in the review (Danhorn, 2007) AHLs (Nacyl- L-homoserine 374 lactones) are the key components of QS signaling system (Danhorn, 2007, Ortíz-Castro et al., 375 2009). Plants identify AHLs and trigger changes in gene expression, defense responses of plants 376 (Ma et al., 2016a).

377 Plants also can form in their roots specific symbiotic associations with microorganisms living in 378 the spaces between cells of the root cortex and providing plants with nitrogen (such as plant379 rhizobia and arbuscular mycorrhiza). The nitrogen-fixing rhizobia associated with legumes (Gray 380 \& Smith, 2005, Djordjevic, Mond-Radzman \& Imin, 2015) as well as mycorrhizal fungi formed 381 a symbiosis with the roots of most vascular plants are well understood (Upadhyaya et al., 2010, 382 Emamverdian et al., 2015). The value of nitrogen fixation is very high for plants, and it is 383 concluded that nitrogen fixation is of great ecological importance as a way to replenish the 384 nitrogen available to plants in most natural ecosystems (Djordjevic, Mond-Radzman \& Imin 385 2015).

386 Bacteria, inhabiting in rhizosphere were classified according to their functional activities 387 (Ahemed, 2019). The following groups PGPR were allocated: rhizomediators (solubilizing the $388 \mathrm{HM}$ and regulating HM availability), phytostimulators (stimulating plant growth because of 389 phytohormone production), biofertilizers increasing soil nutrient availability, biopesticides 390 (controlling plant pathogens and diseases) (Ahemed, 2019). All these properties are important in 391 plant-microbial interactions under HM stress, including biocontrol function, which ensures the systemic resistance of plants (Ahemed, 2019, Manoj et al., 2020). 
393 Despite a fairly long study of the microbial community of plants, our knowledge about it is quite 394 limited (Quiza, St-Arnaud \& Yergeau, 2015). Plant-associated bacteria probably have a different 395 genes enabling adaptation to the plant environment. The studying in this direction is just

396

397

398

399

400

401

402

403

404

405

406

407

408

409

410

411

412

413

414

415

416

417

418

419

420

421

422

beginning. Recently two sets of plant-associated bacteria genes (involved in plant colonization, and microbial competition between plant-associated bacteria) have been revealed in sequencing 484 bacterial genomes of bacterial isolates from roots of Brassicaceae, poplar, and maize (Levy et al., 2018). In addition to that 115 genes, which consist of $2 \%$ of all genes of Pseudomonas simiae (with colonization functions of the root system of Arabidopsis thaliana) were identified (Cole et al., 2017). A little earlier it has been shown, that wild accessions of Arabidopsis thaliana differ in their ability to form associations with Pseudomonas fluorescens, which effects on host health (Haney et al., 2015).

The new data, concerning plant-bacterial communication in the associations, such as plantbacterial signaling in bacterial colonization of plant, quorum-sensing and biofilm formation, both in natural conditions and under Ni stress, increase our knowledge of plant-bacterial associations.

\section{Bacterial defense systems and PGPR mediated plant defense strategies}

PGPR have developed some strategies to eliminate the inhibitory effects of HM toxicity (Qian et al., 2012, Babu, Kim \& Oh, 2013, Ma et al., 2016a, Tiwari \& Lata, 2018, Rana et al., 2020).

These strategies are speculated may be summarized schematically in (1) HM biosorption/precipitation by cell surface; (2) HM efflux pumping out of the cell by the transporter system; (3) HM binding in cell vacuole and other intracellular compartments; (4) exclusion of HM chelates into the extracellular space; and (5) enzymatic redox reaction via conversion of HM cations into a less toxic state. However, detoxification mechanisms are highly affected by the bacterial species and strains (Aktan, Tan \& Icgen, 2013). Herewith one strain can simultaneously possess multiple defense mechanisms (Choudhury, Srivastava, 2001).

Glutathione, intracellular polyphosphate granules, low and high molecular weight proteins and polyoxybutyric acid are involved in the defense system of bacteria when HM is absorbed by bacteria. However, the main defense mechanisms are realized outside bacterial cells, due to a change in the $\mathrm{pH}$ and redox potential of the medium, the mobilization of phosphates or the production of polysaccharides, siderophores and various antioxidant enzymes (Pishchik et al, 
423 2016). The activity of glutathione-reductase was significantly increased in pea plants, (growing 424 under Ni and Zn stresses) after the inoculation with Rhizobium sp. RP5 (Wani, Khan \& Zaidi, 425 2008).

426 Bacterial extracellular polysaccharides (EPS) can bind HM (Ahemad \& Kibret, 2013), these 427 substances can form complex with HM or by forming an effective barrier surrounding the cell 428 (Rajkumar et al., 2010). Bacterial biofilms also may take part in sequestration or accumulation of $429 \mathrm{Ni}$, and other HM, such as Al, Cd, Cu, Cr, Mn, Pb, Se, Zn (Khan et al., 2016). Endophytic 430 bacterium Caulobacter sp. MN13 (alone and in combination with zeolite) reduced Ni uptake by 431 sesame plants due to bacterial EPS and improved biochemical and agronomic parameters of 432 plants (Naveed et al., 2020).

433 PGPR also produce a specific mixture of $\boldsymbol{V O C}$ s (volatile organic compounds) that modulates 434 plant growth hormones and plays important roles in their interactions with plants (Raza \& Shen, 435 2020). It was shown that the rice inoculation with Klebsiella variicola F2, Pseudomonas 436 fluorescens YX2 and Raoultella planticola YL2 lead to accumulation of GB (N,N,N-trimethyl 437 glycine) and its precursor choline and improved water content in leaves (Gou et al., 2015). GB 438 in vivo is both an effective osmoprotectant and a compatible solute (Felitskiy et al., 2004). It was 439 found also, that GB increased under Ni-stress (Sirhindi et al., 2016).

440 PGPR can secrete low molecular weight organic acids which increase $\mathrm{Ni}$ and other HM 441 bioavailability for plant uptake (Becerra-Castro et al. 2011, Almaroai et al, 2012). A number of 442 organic acids such as, citric, oxalic, malonic lactic etc. have chelating properties (Panhwar et al. 443 2013). The salts formed from these organic acids with heavy metals enter the plants. So, Ni444 gluconate and Ni-citrate complexes were found to be present in the cocoa (Peeters et al., 2017). 445 The potential of organic acids producing PGPR was highlighted in review (Rajkumar et al, 446 2012), however there is a controversial study, which did not show significant effect on the 447 mobilization of HM (Evangelou, Ebel \& Schaeffer, 2006, Park et al., 2011). This effect probably 448 was attributed by increasing rhizosphere soil $\mathrm{pH}$, or the presence of base cation saturations, 449 which can decreased HM availability, as it was shown for Ni cations (Giovannetti et al., 2020).

450 Biosurfactants are classified based on their biochemical nature or the producing microbial 451 species. These natural compounds are classified into five major groups liposaccharides, 452 lipopeptides, phospholipids, fatty acids (and neutral lipids), glycolipids (Sarubbo et al., 2015). 
453 PGPR strains from the genera Acinetobacter (alasan, emulsan et al.) Pseudomonas (glycolipid 454 biosurfactant) and Bacillus (surfactin) are found produced biosurfactants (Sarubbo et al., 2015).

455 It was suggested, that biosurfactant molecules play a key role towards development and 456 maintaining biofilms due to maintenance of water channels through the biofilm (Banat, De 457 Rienzo \& Quinn, 2014). Biosurfactants have been successfully employed in the remediation of 458 environments contaminated with heavy metal ions (Sarubo et al., 2015), i.e. the lipopeptide 459 biosurfactants from Bacillus subtilis A21 bound significant quantity of $\mathrm{HM}$, including $32 \% \mathrm{Ni}$ of 460 polluted soil and was proposed for remediation (Singh \& Cameotra, 2013).

461 Siderophores. Because Fe (II) is highly toxic in its free form due to its participation in the 462 Fenton reaction, and $\mathrm{Fe}$ (III) is insoluble in solutions and not bioavailable (Miethke and 463 Marahiel, 2007), the microorganisms have developed an iron absorption strategy through 464 siderophores (Rajkumar et al., 2012; Ashraf et al., 2017, Diecke et al., 2019; Hofmann, Retamal465 Morales \& Tischler, 2020). Siderophore is also reported to suppress the plant pathogens in 466 different plants, such as tomato (Aznar and Dellagi, 2015), pepper (Yu et al., 2011) and maize 467 (Pal et al., 2001) due to its participation in plants induce systemic resistance (ISR) (Bakker, 468 Pieterse \& Van Loon, 2007, Ghosh, Bera \& Chakrabarty, 2020). Siderophores are low molecular 469 - weight metabolites (500-1500 daltons) with high affinities for $\mathrm{Fe}^{3+}$ with stability constants 470 (Andrews, Robinson \& Rodriguez-Quinones, 2003). Depending on the functional group 471 siderophores are generally classified in different groups: hydroxamates, catecholates (including 472 phenolates), carboxylates and mixed type siderophores (Hofmann, Retamal-Morales \& Tischler, 473 2020). However, their structural nature is variable and they bind different metals and even 474 metalloids (Retamal-Morales et al., 2018). Such complexes are transported into the periplasm by 475 TonB-dependent transporters (TBDT), and are transported across the plasma membrane by ATP476 binding cassette $(\mathrm{ABC})$ transporters in both Gram-negative and Gram-positive bacteria (Ghssein 477 \& Matar, 2018). Other metallophores are found and described also for their ability to uptake 478 metals other than iron, such as, for example, nickelophore for nickel (Lebrette et al., 2015), and 479 zincophore for zinc (Bobrov et al., 2017). However, the complexes with Ni are stable, compared 480 to complexes with Fe (Hofmann, Retamal-Morales \& Tischler, 2020). Bacteria can produce 481 more than one siderophore, so Pseudomonas aeruginosa produces pyoverdine and pyochelin 482 (Minandri at al., 2018). The new metallophor pseudopaline from Pseudomonas aeruginosa is 483 known more specific for the chelation of nickel and zinc (Lhospice et al., 2017). 
484 In addition to the main function of supplying microorganisms and plants with iron, other 485 functions of siderophores are described in the literature. We will focus on the most interesting 486 ones concerning the bacterial protective properties against HM stress. The signaling function of 487 siderophores is discussed in literature (Roux, Payne \& Gilmore, 2009; Johnstone \& Nolan, 488 2015). It is suggested, that the siderophore itself, or a metal complex thereof, acts directly as a 489 signaling molecule or a mediator of quorum sensing. (Roux, Payne \& Gilmore, 2009, 490 Dembitsky, Al Quntar \& Srebnik, 2011).

491 PGPR, producing siderophores, generally increase HM bioavailability through complexation 492 reactions (Khan et al., 2017; Sujkowska-Rybkowska et al., 2020). Therefore such PGPR can be 493 used in in phytoremediation to improve the phytoextraction of $\mathrm{Ni}$ and other HM. It was found 494 that more than $80 \%$ of endophytic bacteria increased the production of siderophores in the 495 presence of heavy metals ( $\mathrm{Ni}$ and $\mathrm{Co}, \mathrm{Cr}, \mathrm{Cu}, \mathrm{Zn}$ ) and also reduced metal toxicity in their host 496 plant Alyssum bertolonii (Ma et al., 2011a). Ni- resistant Pseudomonas sp. A3R3 increased 497 plants biomass as well as Ni accumulation in Brassica juncea and A. serpyllifolium, due to ACC498 deaminase, siderophores, IAA activities (Ma et al., 2011b).

499 However, there are the opposite evidences too, that bacterial siderophores bound Ni cations (so 500 as $\mathrm{Pb}$ and $\mathrm{Zn}$ ), decreased Ni contents in plants and protecting plants against HM toxicity (Burd et 501 al. 1998; Dimkpa et al., 2008, Dimkpa, Weinand \& Asch, 2009; Tank and Seraf, 2009), or did 502 not influence on the HM concentrations in plants (Kuffner et al., 2010).

503 The literature analysis allows us to assume that the mechanisms, determining HM uptake by 504 plants with the participation of bacterial siderophores are still remaining unknown. Moreover, 505 there is a need to isolate and analyze new siderophores from different PGPR for the application 506 of these PGPR both in bioremediation and plant protection against biotic stresses.

507 Bacterial phytohormones The PGPR regulate the nutritional and hormonal balance in plants and 508 induce plant tolerance to stress (Spence \& Bais, 2015). The phytohormones synthesis in plant 509 rhizosphere is a mechanism of improvement of plant growth under stress (Etesami, Alikhani \& 510 Hosseini, 2015).

511 The participation of microbial auxins in changing of plant root morphology is well studied.

512 Microbial phytohormones affect the metabolism of endogenous growth regulators in plant tissue 513 and change root morphology under heavy metal stress conditions. Auxin-producing PGPR 514 reduced the effect of HM stress on physiological processes in plants (Pishchik et al., 2009). 
515 Auxin- producing B. megaterium MCR-8 increased growth, contents of total phenols, flavonoids, 516 and activities of SOD, CAT, POD, and APX in inoculated Vinca rosea plants under Ni stress 517 (Khan et al., 2017). Although we found very little literature strongly supporting the involvement 518 of PGPR hormones in plant Ni stress management, we can speculate this topic, based on the non519 specifically plant reactions on the abiotic stress. Overcoming some of the adverse effects of Ni-

520

521

522

523

524

525

526

527

528

529

530

531

532

533

534

535

536

537

538

539

540

\section{Bacterial effects on plant stress-responsive genes}

542 Bacteria regulate major metal responsible and transporter genes expression (Manoj et al., 2020).

543 It was revealed, that the inoculation with endophytic bacteria Enterobacter ludwigii SAK5 and

544 Exiguobacterium indicum SA22 led to increasing of Ni content in rice plants, however the 
545 expression level of stress-responsive genes, such as OsGST (glutathione-s transferase), OsMTP1

546 (HM transporting), and OsPCS1 (phytochelatin synthases) level was lower in treated inoculated

547 plants than in untreated non-inoculated plants which indicated a decrease in stress levels when

548 inoculated with bacteria (Jan et al., 2019). However, the studies of bacterial effect on gene

549 expression in plants under Ni stress are insufficient and further studies are needed. The missing

550 information on micro RNAs mediated by bacterial inoculation under nickel stress is also

551 necessary.

552

553 Bioremediation

554 Taking into consideration the differences in responses of plants and microorganisms to HM,

555 bioremediation employs two different approaches: phytoextraction and phytostabilization.

556 Phytoextraction implies the use of HM-accumulating plants that can accumulate metals in

557 aboveground organs, which are then utilized. Phytostabilization (the conversion of chemicals to

558 less mobile and active forms) can employ plants with high resistance to HM, localizing HM

559 mainly in the root system (Chaney \& Mahoney, 2014). Phytoremediation, an emerging technique

560 makes use of plants and their associated microbes to clean up heavy metals pollutant from soil

561 (Kumar \& Verma, 2018). In addition phytoremediation is cost effective and is a more sustainable

562 approach for removal of HM (Ma et al., 2016b).

563 Streptanthus polygaloides A. Gray, a Ni- hyperaccumulating plant from Brassicaceae family

564 was successfully used in phytoextraction. The shoot Ni concentration of S. polygaloides

565 averaged $5300 \mathrm{mg} \mathrm{kg}^{-1}$, whereas Ni concentration in soil was of $3340 \mathrm{mg} \mathrm{kg}^{-1}$ (Nicks \&

566 Chambers, 1995).

567 During development of Ni phytoextraction technology mean Ni concentrations in the shoots

568 Alissum murale and Alissum corsicum ranged from 4200 to $20400 \mathrm{mg} \mathrm{kg}^{-1}$. Ni uptake by these

569 Alyssum species was reduced in the field experiments at lower soil $\mathrm{pH}$ and increased at higher

570 soil pH, and that was an uninspected result (Li et al., 2003). Nowadays eight species of Alissum

571 (family Brassicaceae) described as Ni-hyperaccumulators (Pollard, Reeves \& Baker, 2014).

572

\section{Conclusions}


574 The review highlights the importance of bacterial contribution in plant protection under Ni-

575 stress. The understanding of the mechanisms of bacterial plant defense against nickel stress in 576 plant-bacterial associations has been formed in recent decades. Bacteria activated numerous

577 genes in plants in response to Ni- stress; however research in this direction is just emerging.

578 Moreover, intensive study of plant genes involved in protection against nickel stress has also

579 taken place in the last decades, when some plant genes have been identified and proposed as

580 candidates for plant protection against nickel stress. Despite the fact that various mechanisms of

581 bacterial protection have already been described in the literature, some issues remain unexplored.

582 So, more detailed studies of the effect of bacterial phytohormones on plants under Ni stress is

583 required for understanding. More information concerning plant-microbial crosstalk in response

584 to Ni-stress is missing; therefore omics-based technologies, such as transcriptomics, proteomics

585 and metabolomics must be used in future experiments to decipher the mechanisms of bacterial

586 protection of plants. Further study of environmental conditions is also necessary, since the

587 effectiveness of the protective actions of bacteria is also determined by soil conditions and the

588 magnitude of the stress load. The review of the scientific data results on the ability of plant-

589 microbial associations to regulate the nickel uptake by plants with subsequent utilization of

590 plant biomass will help to develop bioremediation technologies for polluted lands, or to produce

591 eco-friendly agricultural crops on HM contaminated soils (with the level of Ni and other HM

592 contents not exceeding the maximum permissible concentrations).

593

\section{References}

595 Aina R, Sgorbati S, Santagostino A, Labra M, Ghiani A, Citterioet S. 2004. Specific

596 hypomethylation of DNA is induced by heavy metals in white clover and industrial hemp.

597 Physiologia Plantarum 121(3):472-480 https://doi.org/10.1111/j.1399-3054.2004.00343.x

598 Aina R, Labra M, Fumagalli P, Vannini C, Marsoni M, Cucchi U, Bracale M, Sgorbati S,

599 Citterio S. 2007. Thiol-peptide level and proteomic changes in response to cadmium toxicity in

600 Oryza sativa L. roots. Environmental and Experimental Botany 59(3):381-392

601 https://doi.org/10.1016/j.envexpbot.2006.04.010

602 Ahemed M. 2019. Remediation of metalliferous soils through the heavy metal resistant plant 603 growth promoting bacteria: Paradigms and prospects. Arabian Journal of Chemistry 12: 1365-

6041377 http://dx.doi.org/10.1016/j.arabjc.2014.11.020 
605

606

607

608

609

610

611

612

613

614

615

616

617

618

619

620

621

622

623

624

625

626

627

628

629

630

631

632

633

634

Ahemad M, Kibret M. 2013. Recent trends in microbial biosorption of heavy metals: a review. Biochemistry \& Molecular Biology 1 (1):19-26 https://doi.org/10.12966/bmb.06.02.2013

Akhtar MJ, Ullah S, Ahmad I, Rauf A, Nadeem SM, Khan MY, Hussain S, Bulgariue L. 2018.Nickel phytoextraction through bacterial inoculation in Raphanus sativus.Chemosphere 190:234-242 https://doi.org/10.1016/j.chemosphere.2017.09.136

Aktan Y, Tan S, Icgen B. 2013. Characterization of Lead-Resistant River Isolate

Enterococcus Faecalis and Assessment of its Multiple Metal and Antibiotic Resistance.

Environmental Monitoring and Assessment 185:5285-5293 https://doi.org/10.1007/s10661-012$\underline{2945-\mathrm{X}}$

Almaroai Y, Usman AR, Ahmad M, Kim KR, Moon DH, Lee SS, Ok YS.2012. Effects of Synthetic Chelators and Low-Molecular-Weight Organic Acids on Chromium, Copper, and Arsenic Uptake and Translocation in Maize (Zea mays L.). Soil Science 177(11):655-663 https://doi.org: 10.1097/SS.0b013e31827ba23f

Ameen N, Amjad M, Murtaza B, Abbas Gh, Shahid M, Imran M, Naeem MA, Niazi NK. 2019. Biogeochemical behavior of nickel under different abiotic stresses: toxicity and detoxification mechanisms in plants. Environmental Science and Pollution Research 26:1049610514 https://doi.org/10.1007/s11356-019-04540-4

Amjad M. 2020a. Nickel toxicity induced changes in nutrient dynamics and antioxidant profiling in two maize (Zea mays L.) hybrids. Plants 9:5 https://doi.org/10.3390/plants9010005

Amjad M, Ameen N, Murtaza B, Imran M, Shahid M, Abbas G, Naeem MA, Jacobsen S-E. 2020b. Comparative physiological and biochemical evaluation of salt and nickel tolerance mechanisms in two contrasting tomato genotypes. Physiologia plantarum 168(1):27-37 https://doi.org/10.1111/ppl.12930

Andrews SC, RobinsonA K, Rodríguez-Quiñones F.2003. Bacterial iron homeostasis. FEMS Microbiology Reviews 27 (2-3): 215-237 https://doi.org/10.1016/S0168-6445(03)00055-X

Arefifard M, Mahdieh M, Amirjani M. 2014. Study of the effect of nickel heavy metals on some physiological parameters of Catharanthus roseus. Natural Product Research 28(18):14991502 https://doi.org/10.1080/14786419.2014.913240

Ashraf MY, Sadiq R, Hussain M, Ashraf MMSA, Ahmad. 2011. Toxic effect of nickel (Ni) on growth and metabolism in germinating seeds of sunflower (Helianthus annuus L.). Biological 
635 Trace Element Research 143:1695-1703 https://doi.org/10.1007/s12011-011-8955-7

636 Ashraf MA, Hussain I, Rasheed R, Iqbal M, Riaz M, Arif MS. 2017. Advances in microbe637 assisted reclamation of heavy metal contaminated soils over the last decade: A review. Journal 638 of Environmental Management 198(1):132-143. https://doi.org/10.1016/j.jenvman.2017.04.060

639 Aziz E, Gad N, Badran N. 2007. Effect of cobalt and Ni on plant growth, yield and 640 flavonoids content of Hibiscus sabdariffa L. Australian Journal of Basic and Applied Sciences 641 1(2):73-78 http://ajbasweb.com/old/ajbas/73-78.pdf

642 Aznar A, Dellagi A. 2015. New insights into the role of siderophores as triggers of 643 plantimmunity: what can we learn from animals? Journal of Experimental Botany 66 (11): 30016443010 https://doi.org/10.1093/jxb/erv155

645 Babu AG, Kim JD, Oh BT. 2013.Enhancement of heavy metal phytoremediation by Alnus 646 firma with endophytic Bacillus thuringiensis GDB-1. Journal of Hazardous Materials 250647 251:477-483 https://doi.org/10.1016/j.jhazmat.2013.02.014

648 Baginsky C, Palacios JM, Imperial J, Ruiz-Argueso T, Brito B. 2004. Molecular and 649 functional characterization of the Azorhizobium caulinodans ORS571 hydrogenase gene cluster. 650 FEMS Microbiology Letters 237:399-405 https://doi.org/10.1111/j.1574-6968.2004.tb09723.x

651 Balal R, Shahid M, Javaid M, Anjum M, Ali H, Mattson N, Garcia-Sanchez F. 2016. Foliar 652 treatment with Lolium perenne (Poaceae) leaf extract alleviates salinity and nickel-induced 653 growth inhibition in pea. Brazilian Journal of Botany 39(2):453-463

654 https://doi.org/10.1007/s40415-016-0253-3

655 Bais HP, Weir TL, Perry LG, Gilroy S, Vivanco JM. 2006. The role of root exudates in 656 rhizosphere interactions with plants and other organisms. Annual Review of Plant Biology 657 57:233-266 https://doi.org/10.1146/annurev.arplant.57.032905.105159

658 Banat IM, De Rienzo MAD, Quinn GA. 2014.Microbial biofilms: biosurfactants as 659 antibiofilm agents. Applied Microbiology and Biotechnology 98(24):9915-9929

660 https://doi.org/10.1007/s00253-014-6169-6

661 Bakker PAHM, Pieterse CM, Van Loon LC. 2007. Induced systemic resistance by 662 fluorescent Pseudomonas spp. Phytopathology 97 (2):239-243 https://doi.org/10.1094/PHYTO$663 \quad \underline{97-2-0239}$

664 Becerra-Castro C, A. Prieto-Fernández A, V. Álvarez-Lopez V, Monterroso C, Cabello- 
665 Conejo MI, Acea MJ, Kidd PS. 2011. Nickel solubilizing capacity and characterization of 666 rhizobacteria isolated from hyperaccumulating and non-hyperaccumulating subspecies of 667 Alyssum serpyllifolium. International Journal of Phytoremediation 13(1):229-244

668 https://doi.org/10.1080/15226514.2011.568545

669 Bhatia NP, Walsh KB, Baker AJM. 2005. Detection and quantification of ligands involved 670 in nickel detoxification in a herbaceous Ni hyperaccumulator Stackhousia tryonii Bailey. Journal 671 of Experimental Botany 56 (415):1343-1349 https://doi.org/10.1093/jxb/eri135

672 Bobrov AG, Kirillina O, Fosso MY, Fetherston JD, Miller MC, VanCleave TT, Burlison JA, 673 ArnoldWK, Lawrenz MB, Garneau-Tsodikova S, Perry RD. 2017.Zinc transporters YbtX and $674 \mathrm{ZnuABC}$ are required for the virulence of Yersinia pestis in bubonic and pneumonic plague in 675 mice. Metallomics 9(6): 757-772 https://doi.org/10.1039/c7mt00126f

676 Brencic A, Winans SC. 2005. Detection and response to signals involved in host-microbe 677 interactions by plant-associated bacteria. Microbiology and Molecular Biology Review 678 69(1):155-194 https://doi.org/10.1128/MMBR.69.1.155-194.2005

679 Burd GI, Dixon DG, Glick BR. 1998.Plant growth-promoting bacterium that decreases 680 nickel toxicity in seedlings. Applied and Environmental Microbiology 64(10):3663-3668 681 https://doi.org/10.1128/AEM.64.10.3663-3668.1998

682 Cabanillas A, Ginebreda D, Guillén E, Martínez Barceló D, Moragas L, Robusté J, Darbra 683 RM. 2012. Fuzzy logic based risk assessment of effluents from waste-water treatment plants.

684 Science of The Total Environment 439(15):202-210

685 https://doi.org/10.1016/j.scitotenv.2012.09.008

686 Cabello-Conejo MI, Centofanti T, Kidd PS, Prieto-Fernández Á, Chaney R. 2013.Evaluation 687 of plant growth regulators to increase nickel phytoextraction by Alyssum species. International 688 Journal of Phytoremediation 15 (4):365-375 https://doi.org/10.1080/15226514.2012.702806

689 Cabello-Conejo MI, Prieto-Fernández Á, Kidd PS. 2014. Exogenous treatments with 690 phytohormones can improve growth and nickel yield of hyperaccumulating plants. Science of the 691 Total Environment 494-495:1-8 http://dx.doi.org/10.1016/j.scitotenv.2014.06.102

692 Callahan DL, Roessner U, Dumontet V, De Livera AM, Doronil A, Baker AJM, Kolev SD. 693 2012. Elemental and metabolite profiling of nickel hyperaccumulators from New Caledonia.

694 Phytochemistry 81:80-89 https://doi.org/10.1016/j.phytochem.2012.06.010 
695 Celik Ö, Akdaş EY. Tissue-specific transcriptional regulation of seven heavy metal stress696 responsive miRNAs and their putative targets in nickel indicator castor bean (R. communis L.) 697 plants. 2019. Ecotoxicology and Environmental Safety170:682-690

698 https://doi.org/10.1016/j.ecoenv.2018.12.006

699 Centofanti T, Siebecker M, Chaney R, Davis A, Sparks D. 2012. Hyperaccumulation of 700 nickel by Alyssum corsicum is related to solubility of Ni mineral species. Plant and Soil 359:7170183 https://doi.org/10.1007/s11104-012-1176-9

702 Chaney RL, Mahoney M. 2014. Phytostabilization and phytomining: Principles and 703 successes. Meeting Proceedings. Proc. Life of Mines Conference, July 15-17. 2014. Brisbane 704 Australia. Paper 104.

705 Chaparro JM, Sheflin AM, Manter DK, Vivanco JM. 2012. Manipulating the soil 706 microbiome to increase soil health and plant fertility. Biology and Fertility of Soils 48:489-499 707 https://doi.org/10.1007/s00374-012-0691-4

708 Chen L, Guo Y, Yang L, Wang Q. 2008. Synergistic defensive mechanism of phytochelatins 709 and antioxidative enzymes in Brassica chinensis L. against Cd stress.Chinese Science 710 Bulletin53(10):1503-1511 https://doi.org/10.1007/s11434-008-0062-6

711 Chivers PT, Sauer RT. 2000.Regulation of high affinity nickel uptake in bacteria.Ni 712 dependent interaction of NikR with wild-type and mutant operator sites. Journal of Biological 713 Chemistry 275:19735-19741 https://doi.org/10.1074/jbc.m002232200

714 Choudhury R, Srivastava S. 2001. Zinc resistance mechanisms in bacteria. Current Science. 715 81(7):768-775 https://www.jstor.org/stable/24106396

716 Cobbett CS. 2000. Phytochelatins and their roles in heavy metal detoxification.Plant 717 Physiology 123(3):825-832 https://doi.org/10.1104/pp.123.3.825

718 Cole BJ, Feltcher ME, Waters RJ, Wetmore KM, Mucyn TS, Ryan EM, Gaoyan Wang 719 G,Ul-Hasan S., McDonald M, Yoshikuni Y,Rex R. Malmstrom RR, Deutschbauer AM, Dangl 720 JL, Visel A. 2017. Genome-wide identification of bacterial plant colonization genes. PLoS 721 Biology 15(9):e2002860. https://doi.org/10.1371/journal.pbio.2002860

722 Czajka K, Michael P, Nkongolo KK. 2018. High level of nicotianamine synthase (NAS3) 723 and natural resistance associated macrophage protein (NRAMP4) gene transcription induced by 
724 potassium nitrate in trembling aspen (Populus tremuloides). American Journal of Biochemistry 725 and Biotechnology. 14:183-190 https://doi.org/10.3844/ajbbsp.2018.183.190

726 Dalvi AA, Bhalerao SA. 2013. Response of plants towards heavy metal toxicity: an 727 overview of avoidance, tolerance and uptake mechanism. Annals of Plant Sciences 2(9):362-368 728 https://doi.org/10.1007/978-94-007-4441-7_2

729 Danhorn T, Fuqua C. 2007. Biofilm formation by plant-associated bacteria. Annual Review 730 of Microbiology 61:401-422 https://doi.org/10.1146/annurev.micro.61.080706.093316

731 Deicke M, Mohr JF, Roy S, Herzsprung P, Bellengerd JP, Wichard T. 2019. Metallophore 732 profiling of nitrogen-fixing Frankia spp. to understand metal management in the rhizosphere of 733 actinorhizal plants. Metallomics11 (4): 810-821 https://doi.org/10.1039/C8MT00344K

734 Dembitsky VM, Al Quntar AAA, Srebnik M. 2011.Natural and synthetic small boron735 containing molecules as potential inhibitor of bacterial and fungal quorum sensing. 2011. 736 Chemical Reviews 111 (1):209-237 https://doi.org/10.1021/cr100093b

737 Deng THB, van der Ent A, Tang YT, Sterckeman T, Echevarria G, Morel J-L, Qiu R-L.

738 2018. Nickel hyperaccumulation mechanisms: a review on the current state of knowledge. Plant 739 and Soil 423:1-11 https://doi.org/10.1007/s11104-017-3539-8

740 De Pina K, Desjardin V, Mandrand-Berthelot M-A, Giordano G, Wu L-F. 1999. Isolation 741 and characterization of the nikR gene encoding a nickel-responsive regulator in Escherichia coli. 742 Journal of Bacteriology181: 670-674 https://doi.org/10.1128/JB.181.2.670-674.1999

743 Dimkpa C, Svatoš A, Merten D, Büchel G, Kothe E. 2008. Hydroxamate siderophores 744 produced by Streptomyces acidiscabies E13 bind nickel and promote growth in cowpea (Vigna 745 unguiculata L.) under nickel stress. Canadian Journal of Microbiology 54(3)163-172

746 https://doi.org/10.1139/W07-130

747 Dimkpa C., Weinand T, Asch F. 2009.Plant-rhizobacteria interactions alleviate abiotic 748 stress conditions Plant, Cell and Environment 32, 1682-1694 https://doi.org/10.1111/j.1365$749 \quad \underline{3040.2009 .02028 . x}$

750 Ding H, Nan Z, Liu X, Li Y, Wang S, Qin S, Zhao Z-J. 2008. Characteristics of selected heavy 751 metal pollution in suburb cropland, Jinchang City, Gansu, China. Journal of Agro-Environment 752 Science 27(6):2183-2188

753 Djeukam CL, Nkongolo K. 2018. Expression of genes associated with nickel resistance in red 
754 oak (Quercus rubra) populations from a metal contaminated region. Bulletin of Environmental

755 Contamination and Toxicology100:792-797 https://doi.org/10.1007/s00128-018-2328-2

756 Djordjevic MA, Mond-Radzman NA, Imin N. 2015. Small-peptide signals that control root

757 nodule number, development, and symbiosis. Journal of Experimental Botany 66 (17):5171-

7585181 https://doi.org/10.1093/jxb/erv357

759 Dubey S, Shri M, Gupta A, Rani V, Chakrabarty D. 2018. Toxicity and detoxification of heavy

760 metals during plant growth and metabolism. Environmental Chemistry Letters 16:1169-1192

761 https://doi.org/10.1007/s10311-018-0741-8

762 Egamberdieva D, Abd-Allah EF, da Silva JTA. 2016. Microbially assisted phytoremediation of

763 heavy metal-contaminated soils. In:Parvaiz A (ed) Plant Metal Interaction. Emerging

764 Remediation Techniques. Elsevier Inc; Amsterdam, The Netherlands. pp. 483-498

765 https://doi.org/10.1016/B978-0-12-803158-2.00020-5.

766 Eitinger T, Suhr J, Moore L, Smith JA. 2005. Secondary transporters for nickel and cobalt ions:

767 theme and variations. BioMetals 18: 399- 405 https://doi.org/10.1007/s10534-005-3714-X

768 Eitinger T, Mandrand-Berthelot MA. 2000. Nickel transport systems in microorganisms.

769 Archives of Microbiology 173:1-9 https://doi.org/10.1007/s002030050001

770 Emamverdian A, Ding Y, Mokhberdoran F, Xie Y. 2015. Heavy metal stress and some

771 mechanisms of plant defense response. Scientific World Journal 2015:756120

772 https://doi.org/10.1155/2015/756120

773 Etesami H, Alikhani HA, Hosseini HM. 2015.Indole-3-acetic acid (IAA) production trait, a

774 useful screening to select endophytic and rhizosphere competent bacteria for rice growth

775 promoting agents. Methods X 2:72-78 https://doi.org/10.1016/j.mex.2015.02.008

776 Evangelou MWH, Ebel M, Schaeffer A. 2006. Evaluation of the effect of small organic acidson

777 phytoextraction of $\mathrm{Cu}$ and $\mathrm{Pb}$ from soil with tobacco Nicotiana tabacum. Chemosphere 63

778 (6):996-1004 https://doi.org/10.1016/j.chemosphere.2005.08.042

779 Evdokimova GA, Kalabin GV, Mozgova NP. 2011. Contents and toxicity of heavy metals in

780 soils of the zone affected by aerial emissions from the severonikel enterprise. Eurasian Soil

781 Science 44(2):237-244 https://doi.org/10.1134/S1064229311020037

782 Fabiano CC, Tezotto T, Favarin JL, Polacco JC, Mazzafera P. 2015. Essentiality of nickel in

783 plants: a role in plant stresses. Frontiers in Plant Science 6:754

Peer] reviewing PDF | (2020:10:53459:1:1:NEW 18 Jun 2021) 
784 https://doi.org/10.3389/fpls.2015.00754

785 Felitsky DJ, Cannon JG, Capp MW, Hong J, Van Wynsberghe AW, Anderson CF, Record MT.

786 2004. The exclusion of glycine betaine from anionic biopolymer surface: why glycine betaine is

787 an effective osmoprotectant but also a compatible solute. Biochemistry 43(46):14732-14743

788 https://doi.org/10.1021/bi049115w

789 Ferraz P, Fidalgo F, Almeida A, Teixeira J. 2012. Phytostabilization of nickel by the zinc and

790 cadmium hyperaccumulator Solanum nigrum L. are metallothioneins involved? Plant Physiology

791 and Biochemistry 57:254-260 https://doi.org/10.1016/j.plaphy.2012.05.025

792 Fourati E, Wali M, Vogel-Mikuš K, Abdelly C, Ghnaya T. 2016.Nickel tolerance, accumulation

793 and subcellular distribution in the halophytes Sesuvium portulacastrum and Cakile maritima.

794 Plant Physiology and Biochemistry 108:295-303 https://doi.org/10.1016/j.plaphy.2016.07.024

795 Freeman J, Persans M, Nieman K, Albrecht C, Peer W, Pickering IJ, Salt D. 2004. Increased

796 glutathione biosynthesis plays a role in nickel tolerance in Thlaspi nickel hyperaccumulators.

797 Plant Cell 16:2176-2191 https://doi.org/10.1105/tpc.104.023036

798 Freeman JL, Garcia D, Kim D, Hopf A, Salt DE. 2005. Constitutively elevated salicylic acid

799 signals glutathione-mediated nickel tolerance in Thlaspi nickel hyperaccumulators. Plant

800 physiology 137: 1082-1091 https://doi.org/10.1104/pp.104.055293

801 Fuqua C, Greenberg EP. 2002. Listening in on bacteria: acyl-homoserine lactone signalling.

802 Nature Reviews Molecular Cell Biology 3:685-95 https://doi.org/10.1038/nrm907

803 Gajewska E, Skłodowska M. 2005. Antioxidative responses and proline level in leaves and roots

804 of pea plants subjected to nickel stress. Acta Physiologiae Plantarum 27(3):329-340

805 https://doi.org/10.1007/s11738-005-0009-3

806 Gajewska E, Skłodowska M, Słaba M, Mazur J. 2006. Effect of nickel on antioxidative enzyme

807 activities, proline and chlorophyll contents in wheat shoots. Biologia Plantarum 50(4):653-659

808 https://doi.org/10.1007/s10535-006-0102-5

809 Gajewska E, Skłodowska M. 2007. Effect of nickel on ROS content and antioxidative enzyme

810 activities in wheat leaves. Biometals 20:27-36 https://doi.org/10.1007/s10534-006-9011-5

811 Gajewska E, Skłodowska M. 2009. Nickel-induced changes in nitrogen metabolism in wheat

812 shoots. Journal of Plant Physiology 166(10):1034-1044

813 https://doi.org/10.1016/j.jplph.2008.12.004 
814 García-Domínguez M, Lopez-Maury L, Florencio FJ, Reyes JC. 2000. A gene cluster involved in 815 metal homeostasis in the cyanobacterium Synechocystis sp. strain PCC 6803. Journal of 816 Bacteriology 182:1507-1514 https://doi.org/10.1128/JB.182.6.1507-1514.2000

817 Gerendas J, Zhu Z, Sattelmacher B. 1998. Influence of N and Ni supply on nitrogen metabolism

818 and urease activity in rice Oryza sativa L. Journal of Experimental Botany 49:1545-1554

819 https://doi.org/10.1093/jxb/49.326.1545

820 Ghasemi R, Ghaderian SM, Krämer U. 2009. Interference of nickel with copper and iron

821 homeostasis contributes to metal toxicity symptoms in the nickel hyperaccumulator plant

822 Alyssum inflatum. New Phytologist 184(3):566-580 https://doi.org/10.1111/j.1469-

$823 \quad$ 8137.2009.02993.x

824 Ghosh M, Singh SP. 2005. A review phytoremediation of heavy metals and utilization of it's by825 products. Applied Ecology and Environmental Research 3:1-18

826 https://www.scribd.com/document/50774887/Ghosh-Singh2005-A-review-on-phytoremediation

827 Ghosh SK, Bera T, Chakrabarty A.M. 2020. Microbial siderophore - A boon to agricultural

828 sciences Biological Control 144:104214https://doi.org/10.1016/j.biocontrol.2020.104214

829 Ghssein G, Matar SF. 2018.Chelating mechanisms of transition metals by bacterial

830 metallophores "pseudopaline and staphylopine”: A Quantum Chemical Assessment.Computation

831 6 (4): 56 https://doi.org/10.3390/computation6040056

832 Giovannetti F, Elcio MM, Santos F, Lavresa A. 2020. Agricultural crop influences availability of 833 nickel in the rhizosphere; a study on base cation saturations, Ni dosages and crop succession

834 Rhizosphere 13:100182 https://doi.org/10.1016/i.rhisph.2019.100182

835 Glick BR. 2005. Modulation of plant ethylene levels by the bacterial enzyme ACC deaminase.

836 FEMS Microbiology Letters 251(1):1-7 https://doi.org/10.1016/j.femsle.2005.07.030

837 Gou W, Tian L, Ruan Z, Zheng P, Chen F, Zhang L, Cui Z, Zheng P, Li Z, Gao M, Shi W, 838 Zhang L, Liu J, Hu J. 2015. Accumulation of choline and glycinebetaine and drought stress 839 tolerance induced in maize (Zea mays) by three plant growth promoting rhizobacteria (PGPR)

840 strains. Pakistan Journal of Botany 47:581-586

841 Grass G, Fan B, Rosen BP, Lemke K, Schlegel HG, Rensing C. 2001. NreB from

842 Achromobacter xylosoxidans 31A is a nickel-induced transporter conferring nickel resistance.

843 Journal of Bacteriology 183(9):2803-2807 https://doi.org/10.1128/JB.183.9.2803-2807.2001 
844 Gray EJ, Smith DL. 2005. Intracellular and extracellular PGPR: commonalities and distinctions

845 in the plant-bacterium signaling processes. Soil Biology \& Biochemistry 37(3):395-412

846 https://doi.org/10.1016/j.soilbio.2004.08.030

847 Guo J, Xu L, Su Y, Wang H, Gao S, Xu J, Que Y. 2013. ScMT2-1-3, a metallothionein gene of 848 sugarcane, plays an important role in the regulation of heavy metal tolerance/accumulation.

849 BioMed Research International 2013:904769 https://doi.org/10.1155/2013/904769

850 Guo L, Ding Y, Xu Y, Li Z, Jin Y, He K, Fang Y, Zhao H. 2017. Responses of Landoltia

851 punctata to cobalt and nickel: Removal, growth, photosynthesis, antioxidant system and starch

852 metabolism. Aquatic Toxicology190:87-93. https://doi.org/10.1016/j.aquatox.2017.06.024

853 Gupta V, Jatav PK, Verma R, Kothari S, Kachhwaha S. 2017. Nickel accumulation and its effect

854 on growth, physiological and biochemical parameters in millets and oats.Environmental

855 Scienceand Pollution Research24:23915-23925 https://doi.org/10.1007/s11356-017-0057-4

856 Hall JL. 2002. Cellular mechanisms for heavy metal detoxification and tolerance. Journal of

857 Experimental Botany. 53(366):1-11 https://doi.org/10.1093/jexbot/53.366.1

858 Haney CH, Samuel BS, Bush J, and Ausubel FM. 2015. Associations with rhizosphere bacteria 859 can confer an adaptive advantage to plants. Nature Plants 1:15051

860 https://doi.org/10.1038/nplants.2015.51

861 Haq NU, Raza S, Luthe DS, Heckathorn SA, Shakeel SN. 2013. A dual role for the chloroplast

862 small heat shock protein of Chenopodium album including protection from both heat and metal

863 stress. Plant Molecular Biology Reporter31:398-408 https://doi.org/10.1007/s11105-012-0516-5

864 Hardoim PR, Van Overbeek LS, Van Elsas JD.2008. Properties of bacterial endophytes and their 865 proposed role in plant growth. Trends in Microbiology 16(10):463-471

866 https://doi.org/10.1016/j.tim.2008.07.008

867 Hauser M-T. 2014. Molecular basis of natural variation and environmental control of trichome

868 patterning. Frontiers in Plant Science 5:320 https://doi.org/10.3389/fpls.2014.00320

869 Helaoui S, Boughattas I, Hattab S, Mkhinini M, Alphonse V, Livet A, Bousserrhine N, Banni M.

870 2020. Physiological, biochemical and transcriptomic responses of Medicago sativa to nickel

871 exposure. Chemosphere 249:126121 https://doi.org/10.1016/j.chemosphere.2020.126121

872 Hofmann M, Morales RG, Tischler D. 2020. Metal binding ability of microbial natural metal

873 chelators and potential applications. Natural Product Reports 37 (9):1262-1283 
874 https://doi.org/10.1039/C9NP00058E

875 Hussain MB, Ali S, Azam A, Hina S, Ahsan M, Farooq BA, Bharwana SA, Gill MB. 2013.

876 Morphological, physiological and biochemical responses of plants to nickel stress: A review.

877 African Journal of Agricultural Research 8(17):1596- 1602 https://doi.org/10.5897/AJAR12.407

878 Idris R, Trivonova R, Puschenreiter M, Wenzel WW, Sessitsch A. 2004. Bacterial communities

879 associated with flowering plants of the Ni-hyperaccumulator Thlaspi goesingense. Applied and

880 Environmental Microbiology 70:2667-2677 https://doi.org/10.1128/AEM.70.5.2667-2677.2004

881 Idrees M, Naeema M, Aftab T, Khan MMA. 2013. Salicylic acid restrains nickel toxicity,

882 improves antioxidant defense system and enhances the production of anticancer alkaloids in

883 Catharanthus roseus (L.). Journal of Hazardous Material 252-253:367-374

884 https://doi.org/10.1016/j.jhazmat.2013.03.005

885 Ihedioha JN, Ukoha PO, Ekere NR. 2017 Ecological and human health risk assessment of heavy 886 metal contamination in soil of a municipal solid waste dump in Uyo, Nigeria. Environmental

887 Geochemistry and Health 39:497-515 https://doi.org/10.1007/s10653-016-9830-4

888 Jan R, Khan MA, Asaf S, Lubna, Lee I-J, Kim KM. 2019.Metal resistant endophytic bacteria

889 reduces cadmium, nickel toxicity, and enhances expression of metal stress related genes with

890 improved growth of Oryza sativa, via regulating its antioxidant machinery and endogenous

891 hormones. Plants 8(10):363 https://doi.org/10.3390/plants8100363

892 Jaskulak M, Rorat A, Grobelak A, Chaabene Z, Małgorzata Kacprzak M, Vandenbulcke F. 2019.

893 Bioaccumulation, antioxidative response, and metallothionein expression in Lupinus luteus L.

894 exposed to heavy metals and silver nanoparticles. Environmental Science and Pollution Research

895 26:16040-16052 https://doi.org/10.1007/s11356-019-04972-y

896 Jianfeng W, Zhang Y, Jin J, Li Q, Chenzhou Z, Wenbin N, Xiaomin W, Rongrong M, Yurong B.

897 2017. An intact cytokinin-signaling pathway is required for Bacillus sp. LZR216-promoted plant

898 growth and root system architecture alteration in Arabidopsis thaliana seedlings. Plant Growth

899 Regulation 84:507-518 https://doi.org/10.1007/s10725-017-0357-1

900 Jing Y, He Z, Yang X. 2007. Role of soil rhizobacteria in phytoremediation of heavy metal

901 contaminated soils. Journal of Zhejiang University SCIENCE B 8:192-207

902 https://doi.org/10.1631/jzus.2007.B0192

903 Johnstone TC, Nolan EM 2015 Beyond iron: non-classical biological functions of bacterial 
904 siderophoresDalton Transaction 44: 6320-6339 https://doi.org/10.1039/C4DT03559C

905 Kabata-Pendias A. 2000. Trace elements in soils and plants. CRC Press: Boca Raton, FL, USA

906 Kabata-Pendias A, Mukherjee AB, Arun B. 2007. Trace elements from soil to human. Springer;

907 New York, Berlin, Heidelberg https://doi.org/10. 1007/978-3-540-32714-1

908 Kanwar MK, Bhardwaj R, Chowdhary SPArora P, Sharma P, Kumar S. 2013. Isolation and 909 characterization of 24-Epibrassinolide from Brassica juncea $\mathrm{L}$. and its effects on growth, $\mathrm{Ni}$ ion 910 uptake, antioxidant defense of Brassica plants and in vitro cytotoxicity. Acta Physiologiae 911 Plantarum 35:1351-1362 https://doi.org/10.1007/s11738-012-1175-8

912 Kim S, Takahashi M, Higuchi K, Tsunoda K, Nakanishi H, Yoshimura E, Mori S, Nishizawa 913 NK. 2005. Increased Ni cotianamine biosynthesis confers enhanced tolerance of high levels of 914 metals, in particular nickel, to plants. Plant and Cell Physiology 46(11):1809-1818

915 https://doi.org/10.1093/pcp/pci196

916 Khan N, Seshadri B, Bolan N,Saint C, Kirkham MB, Chowdhury S, Yamaguchi N, Lee DY, Li 917 G, Kunhikrishnan A, Qi F, Karunanithi R, Qiu R, Zhu YG, Syu CH.2016. Root iron plaque on 918 wetland plants as a dynamic pool of nutrients and contaminants. Advances in agronomy138:1-96 919 https://doi.org/10.1016/bs.agron.2016.04.002

920 Khan WU, Ahmad SR, Yasin NA, Ali A, Ahmad A, Akram W. 2017. Application of Bacillus 921 megaterium MCR-8 improved phytoextraction and stress alleviation of nickel in Vinca rosea.

922 International Journal of Phytoremediation 19(9):813-824

923 https://doi.org/10.1080/15226514.2017.1290580

924 Kozlov MV. 2005. Sources of variation in concentrations of nickel and copper in mountain birch 925 foliage near a nickel-copper smelter at Monchegorsk, north-western Russia: results of long-term 926 monitoring. Environmental Pollution 135(1):91-99 https://doi.org/10.1016/j.envpol.2004.10.005

927 Krämer U, Pickering IJ, Prince RC, Raskin I, Salt DE. 2000. Subcellular localization and 928 speciation of nickel in hyperaccumulator and non-accumulator Thlaspi species. Plant Physiology 929 122(4):1343-1354 https://doi.org/10.1104/pp.122.4.1343

930 Kudoyarova GR, Kholodova VP, Veselov DS. 2013. Current state of the problem of water 931 relations in plants under water deficit. Russian Journal of Plant Physiology 60(2):165-175 932 https://doi.org/10.1134/S1021443713020143

933 Kudoyarova GR, Melentiev AI, Martynenko EV, Timergalina LN, Arkhipova TN, Shendel GV, 
934 Kuz'mina LY, Dodd IC, Veselov SY. 2014. Cytokinin producing bacteria stimulate amino acid 935 deposition by wheat roots. Plant Physiology and Biochemistry 83:285-291

936 https://doi.org/10.1016/j.plaphy.2014.08.015

937 Kuffner M, De Maria S, Puschenreiter M, Fallmann K, Wieshammer G, Gorfer M, Strauss J, 938 Rivelli AR, Sessitsch A.Culturable bacteria from Zn- and Cd accumulating Salix caprea with 939 differentialeffects on plant growth and heavy metal availability. Journal of Applied

940 Microbiology108:1471-1484https://doi.org/10.1111/j.1365-2672.2010.04670.x.

941 Kulac S, Cikili Y, Samet H, Filiz E. 2018. Physiological, nutritional, and biochemical responses 942 under nickel toxicity in black poplar (Populus nigra). Journal of BioScience and Biotechnology $9437(2-3): 135-142$

944 Kumar G, Kushwaha HR, Punjabi-Sabharwal V, Kumari S, Joshi R, Karan R, Mittal S, Singla-

945 Pareek SL, Pareek A. 2012. Clustered metallothionein genes are co-regulated in rice and ectopic 946 expression of OsMT1e-P confers multiple abiotic stress tolerance in tobacco via ROS

947 scavenging. BMC Plant Biology 12:107 https://doi.org/10.1186/1471-2229-12-107

948 Kumar A, Verma JP. 2018. Does plant-Microbe interaction confer stress tolerance in plants: A 949 review?Microbiol Res 207:41-52 https://doi.org/10.1016/j.micres.2017.11.004

950 Lee S, Moon JS, Domier LL, Korban SS. 2002.Molecular characterization of phytochelatin 951 synthase expression in transgenic Arabidopsis.Plant Physiology and Biochemistry 40(9)727-733 952 https://doi.org/10.1016/S0981-9428(02)01430-4

953 Lebrette H, Borezée-Durant E, Martin L, Richaud P, Erba B, Cavazza C. 2015 Novel insights 954 into nickel import in Staphylococcus aureus: The positive role of free histidine and structural 955 characterization of a new thiazolidine-type nickel chelator. Metallomics 7 (4):613-621

956 https://doi.org/10.1039/C4MT00295D

957 Lemaire S, Guillon B, Le Marechal P, Keryer E, Miginiac-Maslow M, Decottignies P. 2004.

958 New thioredoxin targets in the unicellular photosynthetic eukaryote Chlamydomonas reinhardtii.

959 Proceedings of National Academy of Sciences of the United States of America1 01(19):7475-

9607480 https://doi.org/10.1073/pnas.0402221101

961 Levy A, Gonzalez IS, Mittelviefhaus M, Clingenpeel S, Paredes SH, Miao J, Wang K,

962 Devescovi G, Kyra K, Monteiro F, Alvarez BR, Lundberg DS, Lu T-Y, Lebeis S, Jin Z,

963 McDonald M, Klein AP, Feltcher ME, Rio TG, Grant SR, Doty SL,E. Ley RE, Zhao B, Venturi 
964 V, Pelletier DA, Vorholt JA, Tringe SG, Woyke T, Dangl JL. 2018. Genomic features of

965 bacterial adaptation to plants. Nature Genetics 50:138-150 https://doi.org/10.1038/s41588-017-

$966 \quad \underline{0012-9}$

967 Lhospice S, Gomez NO, Ouerdane L, Brutesco C, Ghssein G, Hajjar C, Liratni A, Wang S,

968 Richaud P, Bleves S, Ball G, Borezée-Durant E, Lobinski R, Pignol D, Pascal Arnoux P,

969 Voulhoux R. 2017. Pseudomonas aeruginosa zinc uptake in chelating environment is primarily

970 mediated by the metallophorepseudopaline.Scientific Reports

971 7:17132https://doi.org/10.1038/s41598-017-16765-9

972 Li Y-M, Chaney R., Brewer E, Roseberg R, Angle JS, Baker A, Reeves R, Nelkin J. 2003.

973 Development of a technology for commercial phytoextraction of nickel: economic and technical

974 considerations. Plant and Soil 249:107-115 https://doi.org/10.1023/A:1022527330401

975 Liesegang H, Lemke K, Siddiqui RA, Schlegel HG. 1993. Characterization of the inducible

976 nickel and cobalt resistance determinant cnr from pMOL28 of Alcaligenes eutrophus CH34.

977 Journal of Bacteriology 175:767-778 https://doi.org/10.1128/jb.175.3.767-778.1993

978 Liu F, Xing S, Ma H, Du Z, Ma B. 2013. Cytokinin-producing, plant growth-promoting

979 rhizobacteria that confer resistance to drought stress in Platycladus orientalis container

980 seedlings. Applied microbiology and biotechnology 97:9155-9164

981 https://doi.org/10.1007/s00253-013-5193-2

982 Liu F, Hewezi T, Lebeis SL, PantaloneV, Grewal PS, Staton ME. 2019. Soil indigenous

983 microbiome and plant genotypes cooperatively modify soybean rhizosphere microbiome

984 assembly. BMC Microbiology19:201 https://doi.org/10.1186/s12866-019-1572-x

985 Liu X, Hu P, Huang M, Tang Y, Li Y, Li L, Hou X. 2016. The NF-YC-RGL2 module integrates

986 GA and ABA signalling to regulate seed germination in Arabidopsis. Nature Communications

987 7:12768 https://doi.org/10.1038/ncomms12768

988 Llamas A, Sanz A. 2008. Organ-distinctive changes in respiration rates of rice plants under

989 nickel stress. Plant Growth Regulation 54:63-69 https://doi.org/10.1007/s10725-007-9229-4

990 Ma Y, Rajkumar M, Freitas H. 2009.Improvement of plant growth and nickel uptake by nickel

991 resistant-plant-growth promoting bacteria. Journal of Hazardous Materials 166 (2-3):1154-1161

992 https://doi.org/10.1016/j.jhazmat.2008.12.018

993 Ma Y, Prasad MNV, Rajkumar M, Freitas H. 2011a. Plant growth promoting rhizobacteria and 
994 endophytes accelerate phytoremediation of metalliferous soils. Biotechnology Advances 29 (2):

995 248-258 https://doi.org/10.1016/j.biotechadv.2010.12.001

996 Ma Y, Rajkumar M, Luo YM, Freitas H. 2011b. Inoculation of endophytic bacteriaon host and 997 non-host plants e effects on plant growth and Ni uptake. Journal of Hazardous

998 Materials195:230-237 https://doi.org/10.1016/i.jhazmat.2011.08.034

999 Ma Y, Rajkumar M, Rocha I, Oliveira RS, Freitas H. 2015. Serpentine bacteria influence metal 1000 translocation and bioconcentration of Brassica juncea and Ricinus communis grown in multi1001 metal polluted soils. Frontiers in plant science 5:757 https://doi.org/10.3389/fpls.2014.00757 1002 Ma Y, Oliveira RS, Freitas H, Zhang C. 2016a. Biochemical and molecular mechanisms of 1003 plant-microbe-metal interactions: relevance for phytoremediation. Frontiers in plant science 1004 7:918 https://doi.org/10.3389/fpls.2016.00918

1005 Ma Y, Rajkumar M, Zhang Ch, Freitas H. 2016b.The beneficial role of bacterial endophytes in 1006 heavy metal phytoremediation. Journal of Environmental Management 174:14-25

1007 https://doi.org/10.1016/j.jenvman.2016.02.047

1008 Maeda M, Hidaka M, Nakamura A, Masaki H, Uozumi T. 1994. Cloning, sequencing, and 1009 expression of thermophilic Bacillus sp. strain TB-90 urease gene complex in Escherichia coli. 1010 Journal of Bacteriology 176: 432-442 https://doi.org/10.1128/jb.176.2.432-442.1994

1011 Magaye R, Zhao J. 2012. Recent progress in studies of metallic nickel and nickel-based 1012 nanoparticles' genotoxicity and carcinogenicity. Environ Toxicol Pharmacol 34:644-650 1013 https://doi.org/10.1016/j.etap.2012.08.012

1014 Mahmood S, Ishtiaq S, Yasin G, Irshad A. 2016. Dose dependent rhizospheric Ni toxicity 1015 evaluation: Membrane stability and antioxidant potential of Vigna species. Chilean journal of 1016 agricultural research 76(3):378-384 http://dx.doi.org/10.4067/S0718-58392016000300017

1017 Maitra S. 2016. Study of genetic determinants of nickel and cadmium resistance in bacteria - a 1018 review.Journal of Current Microbiology and Applied Sciences 5(11):459-471

1019 http://dx.doi.org/10.20546/ijcmas.2016.511.053

1020 Manna I, Bandyopadhyay M. 2017. Engineered nickel oxide nanoparticle causes substantial 1021 physicochemical perturbation in plants. Frontiers in chemistry 5:92

1022 https://doi.org/10.3389/fchem.2017.00092 
1023 Manoj SR, Karthik C, Kadirvelu K, Arulselvi PI, Shanmugasundaram T, Bruno B, Rajkumar M. 1024 2020.Understanding the molecular mechanisms for the enhanced phytoremediation of heavy 1025 metals through plant growth promoting rhizobacteria: A review. Journal of Environmental 1026 Management 254:109779 https://doi.org/10.1016/j.jenvman.2019.109779

1027 Mari S, Gendre D, Pianelli K, Ouerdane L, Lobinski R, Briat JF, Lebrun M, Czernic P. 2006. 1028 Root - to shoot long-distance circulation of nicotianamine and nicotianamine-nickel chelates in 1029 the metal hyperaccumulator Thlaspi caerulescens. Journal of Experimental Botany57(15):411110304122 https://doi.org/10.1093/jxb/er1184

1031 Maruri-López I, Aviles-Baltazar NY, Buchala A, Serrano M. 2019. Intra and extracellular 1032 journey of the phytohormone salicylic acid. Frontiers in Plant Science 10:423

1033 https://doi.org/10.3389/fpls.2019.00423

1034 McMillan DJ, Mau M, Walker MJ. 1998. Characterisation of the urease gene cluster in 1035 Bordetella bronchiseptica. Gene 208:243-51 https://doi.org/10.1016/S0378-1119(97)00651-3

1036 Mengoni A, Barzanti A, Gonnelli C, Gabrielli R, Bazzicalupo M. 2001. Characterization of 1037 nickel-resistant bacteria isolated from serpentine soil. Environmental Microbiology 3:691-698 1038 https://doi.org/10.1046/j.1462-2920.2001.00243.x

1039 Mergeay M. 1995. Plasmids for heavy metal resistance in Alcaligenseutrophus: Mechanisms and 1040 applications. In: N Ahmed, M Ishaq, OY Khan, F Sarwar (eds) Biotechnology for Environment 1041 and Agriculture. B.C.C. and T Press, Univ. of Karachi:165-177

1042 Miethke M, Marahiel MA. 2007. Siderophore-based iron acquisition and pathogen control. 1043 Microbiology and Molecular Biology Reviews 71(3):413-451

1044 https://doi.org/10.1128/MMBR.00012-07

1045 Mikolay A, Nies DH. 2009. The ABC transporter AtmA is involved in nickel and cobalt 1046 resistance of Cupriavidusmetallidurans strain CH34. Antonie van Leeuwenhoek 4:37-40 1047 https://doi.org/10.1007/s10482-008-9303-6

1048 Minandri F, Imperi F, Frangipani E, Bonchi C, Visaggio D, Facchini M, Pasquali P, Bragonzi A, 1049 Visca P. 2016. Role of iron uptake systems in Pseudomonas aeruginosa virulence and airway 1050 infection. Infection and Immunity 84:2324-2335 https://doi.org/10.1128/IAI.00098-16

1051 Mirza N, Mahmood Q, Shah MM, Pervez A, Sultan S. 2014. Plants as useful vectors to reduce 1052 environmental toxic arsenic content. Scientific World Journal 2014:921581 
1053 https://doi.org/10.1155/2014/921581

1054 Mittler R, Vanderauwera S, Gollery M, Van Breusegem F. 2004. Reactive oxygen gene network 1055 of plants.Trends in Plant Science 9(10):490-498https://doi.org/10.1016/j.tplants.2004.08.009

1056 Mizuno T, Sonoda T, Horie K, Senoo K, Tanaka A, Mizuno N, Obata H. 2003. Cloning and 1057 characterization of phytochelatin synthase from a nickel hyperaccumulator Thlaspi japonicum 1058 and its expression in yeast. Soil Science and Plant Nutrition 49(2):285-290

1059 https://doi.org/10.1080/00380768.2003.10410009

1060 Mulrooney SB, Hausinger RP. 2003. Nickel uptake and utilization by microorganisms. FEMS

1061 Microbiology Reviews 27:239-261 https://doi.org/10.1016/S0168-6445(03)00042-1

1062 Nakazawa R, Ozawa T, Naito T, Kameda Y, Takenaga H. 2001. Interactions between cadmium 1063 and nickel in phytochelatin biosynthesis and the detoxification of the two metals in

1064 suspensioncultured tobacco cells. Biologia Plantarum 44:627-630

1065 https://doi.org/10.1023/A:1013727728036

1066 Najafi KS, Karimi N, Ghasempour H-R. 2019. Salicylic acid and jasmonic acid restrains nickel

1067 toxicity by ameliorating antioxidant defense system in shoots of metallicolous and non-

1068 metallicolous Alyssum inflatum Náyr. populations. Plant Physiology and Biochemistry 135:450-

1069459 https://doi.org/10.1016/j.plaphy.2018.11.015

1070 Naveed M, Bukhari SS, Mustafa A, Ditta A, Alamri S, El-Esawi MA, Rafique M, Ashraf S, 1071 Siddiqui MH. 2020. Mitigation of nickel toxicity and growth promotion in sesame through the 1072 application of a bacterial endophyte and zeolite in nickel contaminated Soil. International

1073 Journal of environmental research and public health 17(23):8859

1074 https://doi.org/10.3390/ijerph17238859

1075 Naz I, Bano A, Ul-Hassan T. 2009. Isolation of phytohormones producing plant growth 1076 promoting rhizobacteria from weeds growing in Khewra salt range, Pakistan and their 1077 implication in providing salt tolerance to Glycine max L. African Journal of Biotechnology 1078 8(21):5762-5766 https://doi.org/10.5897/AJB09.1176

1079 Nedjimi B. 2021. Phytoremediation: a sustainable environmental technology for heavy metals 1080 decontamination. SN Applied Sciences. 3:286 https://doi.org/10.1007/s42452-021-04301-4

1081 Nies DH, Nies A, Chu L, Silver S. 1989. Expression and nucleotide sequence of a plasmid1082 determined divalent cation efflux system from Alcaligeneseutrophus. Proceedings of theNational 
1083 Academy of Sciences of the USA86:7351-7355 https://doi.org/10.1073/pnas.86.19.7351

1084 Nicks LJ, Chambers MF. 1995. Farming for metals. Mining Environ Manage 3(3):5-18

1085 Nishida S, Tsuzuki C, Kato A, Aisu A, Yoshida J, Mizuno T. 2011. AtIRT1, the primary iron

1086 uptake transporter in the root, mediates excess nickel accumulation in Arabidopsis thaliana.

1087 Plant and Cell Physiology 52(8):1433-1442 https://doi.org/10.1093/pcp/pcr089

1088 Nishida S, Aisu A, Mizuno T. 2012. Induction of IRT1 by the nickel-induced iron-deficient

1089 response in Arabidopsis. Plant Signaling \& Behavior 7(3):329-331

1090 https://doi.org/10.4161/psb.19263

1091 Noctor G, Reichhel J-P, Foyer CH. 2018.ROS-related redox regulation and signaling in plants.

1092 Seminars in Cell \& Developmental Biology 80:3-12

1093 https://doi.org/10.1016/j.semcdb.2017.07.013

1094 Ortíz-Castro R, Contreras-Cornejo HA, Macías-Rodríguez L, López-Bucio J. 2009. The role of 1095 microbial signals in plant growth and development. Plant Signaling and Behavior 4(8):701-712 1096 https://doi.org/10.4161/psb.4.8.9047

1097 Panhwar QA, Jusop S, Naher UA, Othman R, Razi MI. 2013. Application of potential

1098 phosphate-solubilizing bacteria and organic acids on phosphate solubilization from phosphate

1099 rock in aerobic rice.The Scientific World Journal Article ID 272409:10

1100 http://dx.doi.org/10.1155/2013/272409

1101 Pal KK, Tilak KVBR, Saxcna AK, Dey R, Singh CS. 2001. Suppression of maize root diseases

1102 caused by Macrophomina phaseolina, Fusarium moniliforme and Fusarium graminearum by

1103 plant growth promoting rhizobacteria. Microbiological Research 156(3):209 - 223

1104 https://doi.org/10.1078/0944-5013-00103

1105 Pandey N, Sharma CP. 2002. Effect of heavy metal $\mathrm{Co}^{2+}, \mathrm{Ni}^{2+}$ and $\mathrm{Cd}^{2+}$ on growth and

1106 metabolism of cabbage. Plant Science 163(4):753-758 https://doi.org/10.1016/S0168-

$1107 \quad \underline{9452(02) 00210-8}$

1108 Parida BK, Chhibba IM, Nayyar VK. 2003. Influence of nickel contaminated soils on fenugreek

1109 (Trigonella corniculata L.) growth and mineral composition. Scientia Horticulturae 98(2):113-

1110119 https://doi.org/10.1016/S0304-4238(02)00208-X

1111 Parlak KU. 2016. Effect of nickel on growth and biochemical characteristics of wheat

1112 (Triticumaestivum L.) seedlings. NJAS - Wageningen Journal of Life Sciences 76:1-5 
1113 https://doi.org/10.1016/j.njas.2012.07.001

1114 Park JH, Bolan N, Megharaj M, Naidu R. 2011. Isolation of phosphate solubilizing bacteria and

1115 their potential for lead immobilization in soil.Journal of Hazardous Materials 185:829-

1116 836https://doi.or,g/10.1016/j.jhazmat.2010.09.095

1117 Pasternak T, Groot EP, Kazantsev FV, Teale W, Omelyanchuk N, Kovrizhnykh V, Palme K,

1118 Mironova VV. 2019. Salicylic acid affects root meristem patterning via auxin distribution in

1119 aconcentration-dependent manner. Plant Physiology 180:1725-

1120 1739https://doi.org/10.1104/pp.19.00130

1121 Peeters K, Zuliani T, Žigon D, Milačič R, Ščančar J. 2017. Nickel speciation in cocoa infusions

1122 using monolithic chromatography - Post-column ID-ICP-MS and Q-TOF-MS. Food Chemistry

1123230 (1):327-335https://doi.org/10.1016/j.foodchem.2017.03.050

1124 Pena LB, Zawoznik MS, Tomaro ML, Gallego SM. 2008. Heavy metals effects on proteolytic

1125 system in sunflower leaves. Chemosphere 72(5):741-746

1126 https://doi.org/10.1016/j.chemosphere.2008.03.024

1127 Pérez-Palacios P, Romero-Aguilar A, Delgadillo J, Doukkali B, Caviedes MA, Rodríguez-

1128 Llorente ID, Pajuelo E. 2017. Double genetically modified symbiotic system for improved $\mathrm{Cu}$

1129 phytostabilization in legume roots. Environmental Science and Pollution Research 24:14910-

113014923 https://doi.org/10.1007/s11356-017-9092-4

1131 Peroza EA, Freisinger E. 2007. Metal ion binding properties of Tricium aestivum Ec-1

1132 metallothionein: evidence supporting two separate metal thiolate clusters. JBIC Journal of

1133 Biological Inorganic Chemistry 12:377-391 https://doi.org/10.1007/s00775-006-0195-5

1134 Persans MW, Nieman K, Salt DE. 2001. Functional activity and role of cation-efflux family

1135 members in Ni hyperaccumulation in Thlaspi goesingense. Proceedings of the National Academy

1136 of Sciences of the USA98(17):9995-10000 https://doi.org/10.1073/pnas.171039798

1137 Pietrini F, Iori V, Cheremisina A, Shevyakova NI, Radyukina N, Kuznetsov VV, Zacchini M.

1138 2015. Evaluation of nickel tolerance in Amaranthus paniculatus L. plants by measuring

1139 photosynthesis, oxidative status, antioxidative response and metal-binding molecule content.

1140 Environmental Science and Pollution Research 22:482-494 https://doi.org/10.1007/s11356-014-

$1141 \quad \underline{3349-\mathrm{y}}$

1142 Pishchik VN, Provorov NA, Vorobyov NI, Chizevskaya EP, Safronova VI, Kozhemyakov AP, 
1143 Tuev AN. 2009. Interactions between plants and associated bacteria in soils contaminated with

1144 heavy metals. Microbiology 78:785-793 https://doi.org/10.1134/S0026261709060162

1145 Pishchik VN, Vorob'ev NI, Provorov NA, KhomyakovYuV. 2016. Mechanisms of plant and

1146 microbial adaptation to heavy metals in plant-microbial systems. Microbiology 85(3):257-271

1147 https://doi.org/10.1134/S0026261716030097

1148 Pollard AJ, Reeves RD, Baker AJM. 2014. Facultative hyperaccumulation of heavy metals and

1149 metalloids. Plant Science 217-218:8-17 https://doi.org/10.1016/j.plantsci.2013.11.011

1150 Prasad SM, Dwivedi R, Zeeshan M. 2005. Growth, photosynthetic electron transport, and

1151 antioxidant responses of young soybean seedlings to simultaneous exposure of nickel and UV-B

1152 stress. Photosynthetica 43:177-185 https://doi.org/10.1007/s11099-005-0031-0

1153 Qian J, Li D, Zhan G, Zhang L, Su W, Gao P. 2012. Simultaneous biodegradation of Ni-citrate

1154 complexes and removalof nickel from solutions by Pseudomonas alcaliphila. Bioresource

1155 Technology 116:66-73 https://doi.org/10.1016/j.biortech.2012.04.017

1156 Quiza L, St-Arnaud M, Yergeau E. 2015. Harnessing phytomicrobiome signaling for rhizosphere

1157 microbiome engineering. Frontiers in plant science 6:507

1158 https://doi.org/10.3389/fpls.2015.00507

1159 Rao KVM, Sresty TVS. 2000. Antioxidative parameters in the seedlings of pigeonpea

1160 (Cajanuscajan (L.) Millspaugh) in response to Zn and Ni stresses. Plant Science 157:113-128

1161 https://doi.org/10.1016/S0168-9452(00)00273-9

1162 Rajkumar M, Ma Y, Freitas H. 2013. Improvement of Ni phytostabilization by inoculation of Ni

1163 resistant Bacillus megaterium SR28C. Journal of Environmental Management 128:973-980

1164 https://doi.org/10.1016/j.jenvman.2013.07.001

1165 Rajkumar M, Sandhya S, Prasad MNV, Freitas H. 2012. Perspectives of plant associated

1166 microbes in heavy metal phytoremediation. Biotechnology Advances 30(6):1562-1574

1167 https://doi.org/10.1016/j.biotechadv.2012.04.011

1168 Rajkumar M, Ae N, Prasad MNV, Freitas H. 2010. Potential of siderophore-producing bacteria

1169 for improving heavy metal phytoextraction. Trends in biotechnology 28:142-

1170 149https://doi.org/10.1016/j.tibtech.2009.12.002

1171 Rajindiran S, Dotaniya ML, Coumar MV, Panwar NR, Saha JK. 2015. Heavy metal polluted

1172 soils in India: status and countermeasures. JNKVV Reseach Journal 49(3):320-337

Peer] reviewing PDF | (2020:10:53459:1:1:NEW 18 Jun 2021) 
1173 https://www.researchgate.net/publication/296514347 Heavy metal polluted Soils in India sta 1174 tus and countermeasures

1175 Raza W, Shen Q. 2020. Volatile organic compounds mediated plant-microbe interactions in soil.

1176 In: Molecular Aspects of Plant Beneficial Microbes in Agriculture, Chapter 17:209-219

1177 https://doi.org/10.1016/B978-0-12-818469-1.00018-3

1178 Reeves RD, Baker AJM. 2000. Metal-accumulating plants. In: I Raskin, BD Ensley (eds)

1179 Phytoremediation of Toxic Metals - Using Plants to Clean Up the Environment. John Wiley \&

1180 Sons, New York :193-229

1181 Reis AR, Barcelos JPQ, Osório CRWS, Santos EF, Lisboa LAM, Santini JMK, Santos MJD, 1182 Junior EF, Campos M, Figueiredo PAM, Lavres J, Gratão PL. 2017. A glimpse into the 1183 physiological, biochemical and nutritional status of soybean plants under Ni-stress conditions.

1184 Environmental and Experimental Botany 144:76-87

1185 https://doi.org/10.1016/j.envexpbot.2017.10.006

1186 Retamal-Morales G, Mehnert M, Schwabe R, Tischler D, Zapata C, Chávez R, Schlömann M, 1187 Levicán G. 2018. Detection of arsenic-binding siderophores in arsenic-tolerating Actinobacteria 1188 by a modified CAS assay. Ecotoxicology and Environmental Safety 157:176-

1189 181https://doi.org/10.1016/j.ecoenv.2018.03.087

1190 Rizvi A, Bilal A, Zaidi A, Khan MS 2019. Heavy metal mediated phytotoxic impact on winter 1191 wheat: oxidative stress and microbial management of toxicity by Bacillus subtilis BM2. RSC 1192 Advances 9:6125-6142 https://doi.org/10.1039/C9RA00333A

1193 Rizwan M, Imtiaz M, Dai Z, Mehmood S, Adeel M, Liu J, Tu S. 2017. Nickel stressed responses 1194 of rice in Ni subcellular distribution, antioxidant production, and osmolyte accumulation.

1195 Environmental Science and Pollution Research 24:20587-20598 https://doi.org/10.1007/s11356$1196 \quad \underline{017-9665-2}$

1197 Rodrigue A, Effantin G, Berthelot MAM. 2005. Identification of $r c n A$ (yohM) a nickel and cobalt 1198 resistance gene in Escherichia coli. Journal of Bacteriology 187(8):2912-2916

1199 https://doi.org/10.1128/JB.187.8.2912-2916.2005

1200 Roux A, Payne SM, Gilmore MS. 2009. Microbial telesensing: probing the environment for 1201 friends, foes, and food. Cell Host and Microbe 6(2):115-124

1202 https://doi.org/10.1016/j.chom.2009.07.004 
1203 Roy M, Mcdonald LM. 2015. Metal uptake in plants and health risk assessments in metal-

1204 contaminated smelter soils. Land Degradation and Development 26:785-792

1205 https://doi.org/10.1002/LDR.2237

1206 Sachan P, Lal N. 2017. An overview of nickel $\left(\mathrm{Ni}^{2+}\right)$ essentiality, toxicityand tolerance strategies

1207 in plants.Asian Journal of Biology 2(4):1-15 https://doi.org/10.9734/AJOB/2017/33931

1208 Saif S, Khan MS. 2018. Assessment of toxic impact of metals on proline, antioxidant enzymes,

1209 and biological characteristics of Pseudomonas aeruginosa inoculated Cicer arietinum grown in

1210 chromium and nickel-stressed sandy clay loam soils. Environmental Monitoring and Assessment

1211 190:290 https://doi.org/10.1007/s10661-018-6652-0

1212 Sarubbo LA, Rocha JrRB, Luna JM, Rufino RD, Santos VA, Banat IM. 2015. Some aspects of

1213 heavy metals contamination remediation and role of biosurfactants. Chemistry and

1214 Ecology31(8):707-723http://dx.doi.org/10.1080/02757540.2015.1095293

1215 Sirhindi G, Mir MA, Abd-Allah EF, Ahmad P, Gucel S. 2016. Jasmonic acid modulates the

1216 physio-biochemical attributes, antioxidant enzyme activity, and gene expression in glycine max

1217 under nickel toxicity. Frontiers in Plant Science 7:591 https://doi.org/10.3389/fpls.2016.00591

1218 Schmidt T, Schlegel HG. 1989. Nickel and cobalt resistance of various bacteria isolated from

1219 soil and highly polluted domestic and industrial wastes. FEMS Microbiology Ecology 5(5):315-

1220328 https://doi.org/10.1016/0378-1097(89)90014-1

1221 Schützendübel A, Polle A. 2002. Plant responses to abiotic stresses: heavy metal-induced

1222 oxidative stress and protection by mycorrhization. Journal of Experimental Botany

1223 53(372):1351-1365 https://doi.org/10.1093/jexbot/53.372.1351

1224 Seregin IV, Kozhevnikova AD. 2006. Physiological role of nickel and its toxic effects on higher

1225 plants. Rus J Plant Physiol 53:257-277 https://doi.org/10.1134/S1021443706020178

1226 Shahzad B, Tanveera M, Rehman A, Cheema SA, Fahad S, Rehman S, Sharma A. 2018. Nickel;

1227 whether toxic or essential for plants and environment - A review. Plant Physiology and

1228 Biochemistry 132:641-651 https://doi.org/10.1016/j.plaphy.2018.10.014

1229 Shahzad B, Tanveer M, Che Z, Rehman A, SardarAlam Cheema SA, Sharmad A, Song H,

1230 Rehmane S, Zhaorong D. 2018. Role of 24-epibrassinolide (EBL) in mediating heavy metal and 1231 pesticide induced oxidative stress in plants: A review. Ecotoxicology and Environmental Safety 1232 147:935-944 http://dx.doi.org/10.1016/j.ecoenv.2017.09.066 
1233 Sharma A, Sidhu GPS, Araniti F, Bali AS, Shahzad B, Tripathi DK, Brestic M, Skalicky M, 1234 Landi M. 2020. The role of salicylic acid in plants exposed to heavy metals. Molecules25(3):540 1235 https://doi.org/10.3390/molecules 25030540

1236 Sharma SS, Dietz K-J. 2009. The relationship between metal toxicity and cellular redox 1237 imbalance. Trends in Plant Science 14(1):43-50 https://doi.org/10.1016/j.tplants.2008.10.007

1238 Shukla D, Tiwari M, Tripathi RD, Nath P, Trivedi PK. 2013. Synthetic phytochelatins 1239 complement a phytochelatin deficient Arabidopsis mutant and enhance the accumulation of 1240 heavy metal(loid)s. Biochemical and Biophysical Research Communications 434(3)664-669 1241 https://doi.org/10.1016/j.bbrc.2013.03.138

1242 Siddiqui MH, Al-Whaibi MH, Ali HM, Sakran AM, Basalah MO, Al Khaishany MYY. 2013. 1243 Mitigation of nickel stress by the exogenous application of salicylic acid and nitric oxide in 1244 wheat. Australian Journal of Crop Science 7(11):1780-1788

1245 https://cropj.com/siddique 7 11_2013_1780_1788.pdf

1246 Singh AK, Cameotra SS. 2013. Efficiency of lipopeptidebiosurfactants in removal of petroleum 1247 hydrocarbons and heavy metals from contaminated soil. Environmental Science and Pollution 1248 Research 20:7367-7376 https://doi.org/10.1007/s11356-013-1752-4

1249 Singh G, Agnihotri RK, Reshma RS, Ahmad M. 2012. Effect of lead and nickel toxicity on 1250 chlorophyll and proline content of Urd (Vigna mungo L.) seedlings. International Journal of 1251 Plant Physiology and Biochemistry 4(6):136-141 https://doi.org/10.5897/IJPPB12.005

1252 Smith DL, Gravel V, Yergeau E. 2017. Editorial: signaling in the phytomicrobiome. Frontiers in 1253 Plant Science 8:611 https://doi.org/10.3389/fpls.2017.00611

1254 Soares C, de Sousa A, Pinto A, Azenha M, Teixeira J, Azevedo AR, Fidalgo F. 2016. Effect of 1255 24-epibrassinolide on ROS content, antioxidant system, lipid peroxidation and Ni uptake in 1256 Solanum nigrum L. under Ni stress. Environmental and Experimental Botany 122:115-125 1257 https://doi.org/10.1016/j.envexpbot.2015.09.010

1258 Song P, Wen D, Guo ZX, Korakianitis T. 2008. Oxidation investigation of nickel nanoparticles. 1259 Chemistry Chemical Physics 10:5057-5065 https://doi.org/10.1039/b800672e

1260 Song W-Y, Mendoza-Cózatl DG, Lee Y, Schroeder JI, Ahn S-N, Lee H-S, Wicker T, Martinoia 1261 E. 2014. Phytochelatinmetal (loid) transport into vacuoles shows different substrate preferences 1262 in barley and Arabidopsis. Plant, Cell and Environment 37(5):1192-1201 
1263 https://doi.org/10.1111/pce.12227

1264 Song Y, Zhang L, Li J, He X, Chen M, Deng Y. 2018. High-potential accumulation and

1265 tolerance in the submerged hydrophyte Hydrilla verticillata (L.) Royle for nickel-contaminated

1266 water. Ecotoxicology and Environmental Safety 16:553-562

1267 https://doi.org/10.1016/j.ecoenv.2018.06.032

1268 Spence C, Bais H. 2015. The role of plant growth regulators as chemical signals in plant-

1269 microbe interactions: a double edged sword. Current Opinion in Plant Biology 27:52-58

1270 https://doi.org/10.1016/j.pbi.2015.05.028

1271 Sreekanth T, Nagajyothi P, Lee K, Prasad T. 2013. Occurrence, physiological responses and

1272 toxicity of nickel in plants. International Journal of Environmental Science and Technology

1273 10(5):1129-1140 https://doi.org/10.1007

1274 Stahler FN, Odenbreit S, Haas R, Wilrich J, Van Vliet AH, Kusters JG, Kist M, Bereswill S.

1275 2006. The novel CznABC metal efflux pump is required for cadmium, zinc, and nickel

1276 resistance, urease modulation, and gastric colonization. Infection and Immunity 74:3845-3852

1277 https://doi.org/10.1128/IAI.02025-05

1278 Stearns J, Shah S, Greenbeerg B, Dixon DG, Glick BR. 2005.Tolerance of transgenic canola

1279 expressing1-aminocyclopropane-1-carboxylic acid deaminase to growth inhibition by nickel.

1280 Plant Physiology and Biochemistry 43(7):701-708 https://doi.org/10.1016/j.plaphy.2005.05.010

1281 Stetsenko LA, Shevyakova NI, Rakitin VY Kuznetsov VV. 2011. Proline protects Atropa

1282 belladonna plants against nickel salt toxicity. Russian Journal of Plant Physiology 58:337-343

1283 https://doi.org/10.1134/S102144371102021X

1284 Sujkowska-Rybkowska M, Kasowska D, Gediga K, Banasiewicz J, Stępkowski T. 2020. Lotus

1285 corniculatus-rhizobia symbiosis under Ni, Co and $\mathrm{Cr}$ stress on ultramafic soil. Plant and Soil

1286 451:459 https://doi.org/10.1007/s11104-020-04546-9

1287 Taiz L, Zeiger E. 2006. Plant Physiology, fourth ed. Sinauer Associates, Inc; Sunderland,

1288 Massachusetts https://www.journals.uchicago.edu/doi/10.1086/658450

1289 Talebi M, Ebrahim B, Tabatabaei S, Akbarzadeh H. 2019. Hyperaccumulation of Cu, Zn, Ni, and

$1290 \mathrm{Cd}$ in Azolla species inducing expression of methallothionein and phytochelatin synthase genes.

1291 Chemosphere 230:488e497 https://doi.org/ 10.1016/j.chemosphere.2019.05.098

1292 Tank N, Saraf M. 2009. Enhancement of plant growth and decontamination of nickel-spiked 
1293 soil using PGPR. Journal of Basic Microbiology 49(2):195-204

1294 https://doi.org/10.1002/jobm.200800090

1295 Thakur S, Sharma SS. 2016. Characterization of seed germination, seedling growth, and

1296 associated metabolic responses of Brassica juncea L. cultivars to elevated nickel concentrations.

1297 Protoplasma 253:571-580 https://doi.org/10.1007/s00709-015-0835-0

1298 Theriault G, Michael P, Nkongolo K. 2016. Comprehensive transcriptome analysis of response

1299 to nickel stress in white birch (Betula papyrifera). PLoS ONE 11(4):e0153762

1300 https://doi.org/10.1371/journal.pone.015376

1301 Tiwari S. Lata C. 2018. Heavy metal stress, signaling, and tolerance due to plant-associated

1302 microbes: an overview. Frontiers in Plant Science9:452 https://doi.org/10.3389/fpls.2018.00452

1303 Tsyganov VE, Tsyganova AV, Gorshkov AP, Seliverstova EV, Kim VE, Chizhevskaya EP,

1304 Belimov AA, Serova TA, Ivanova KA, Kulaeva OA, Kusakin PG, Kitaeva AB, Tikhonovich IA.

1305 2020. Efficacy of a plant-microbe system: Pisum sativum (L.) cadmium-tolerant mutant and

1306 Rhizobium leguminosarum strains, expressing pea metallothionein genes PsMT1 and PSMT2, for

1307 cadmium phytoremediation. Frontiers in Microbiology 11:15

1308 https://doi.org/10.3389/fmicb.2020.00015

1309 Ude S, Arnold DL, Moon CD, Timms-Wilson T, Spiers AJ. 2006. Biofilm formationand

1310 cellulose expression among diverse environmental Pseudomonas isolates. Environmental

1311 Microbiology 8(11):1997-2011 https://doi.org/10.1111/j.1462-2920.2006.01080.x

1312 Upadhyaya H, Panda SK, Bhattacharjee MK, Dutta S. 2010. Role of arbuscular mycorrhiza in

1313 heavy metal tolerance in plants: prospects for phytoremidiation. Journal of Phytology 2(7):16-27

1314 Vandenkoornhuyse P, Quaiser A, Duhamel M, Le Van A, Dufresne A. 2015. The importance of

1315 the microbiome of plant holobiont. New Phytologist 206(4):1196-1206

1316 https://doi.org/10.1111/nph.13312

1317 Viehweger K. 2014. How plants cope with heavy metals. Botanical Studies 55(35):1-12

1318 https://doi.org/10.1186/1999-3110-55-35

1319 Visioli G, Gulli M, Marmiroli N. 2014. Noccaeacaerulescens populations adapted to grow in 1320 metalliferous and nonmetalliferous soils: Ni tolerance, accumulation and expression analysis of 1321 genes involved in metal homeostasis. Environmental and Experimental Botany 105:10-17

1322 https://doi.org/10.1016/j.envexpbot.2014.04.001 
1323 VodyanitskiiYuN, Plekhanova IO, Prokopovich EV, Savichev AT. 2011. Soil contamination 1324 with emissions of non-ferrous metallurgical plants. Eurasian Soil Science 44(2):217-226 1325 https://doi.org/10.1134/S1064229311020177

1326 Wani PA, Khan MS, Zaidi A. 2008.Effect of heavy metal toxicity on growth, symbiosis, seed 1327 yield and metal uptake in pea grown in metal amended soil. Bull environmental contamination 1328 and toxicology 81:152-158 https://doi.org/10.1007/s00128-008-9383-z

1329 Wang H-C, Wu J-S, Chia J-C, Yang C-C, Wu Y-J, Juang R-H. 2009a. Phytochelatin synthase is 1330 regulated by protein phosphorylation at a threonine residue near its catalytic site. Journal of 1331 Agricultural and Food Chemistry 57(16):7348-7355 https://doi.org/10.1021/jf9020152

1332 Wang H, Feng T, Peng X, Yan M, Tang X. 2009. Up-regulation of chloroplasticantioxidant 1333 capacity is involved in alleviation of nickel toxicity of Zea mays L. by exogenous salicylic acid. 1334 Ecotoxicology and Environmental Safety 72(5):1354-1362

1335 https://doi.org/10.1016/j.ecoenv.2009.03.008

1336 Wu X, Zhu ZB, Chen JH, Huang YF, Li Liu ZI, Zou JW, Chen HY, Su NN, Cui J. 2019.

1337 Transcriptome analysis revealed pivotal transporters involved in the reduction of cadmium 1338 accumulation in pakchoi (Brassica chinensis L.) by exogenous hydrogen-rich water.

1339 Chemosphere 216:684e697 https://doi.org/10.1016/j.chemosphere.2018.10.152

1340 Yang XE, Baligar VC, Foster JC, Martens DC 1997. Accumulation and transport of nickel in 1341 relation to organic acids in ryegrass and maize grown with different nickel levels. In: Ando T, 1342 Fujita K, Mae T, Matsumoto H, Mori S, Sekiya J. (eds) Plant Nutrition for Sustainable Food 1343 Production and Environment. Developments in Plant and Soil Sciences 78:385-390

1344 https://doi.org/10.1007/978-94-009-0047-9 116

1345 Yu X, Ai C, Xin L, Zhou G. 2011. The siderophore-producing bacterium, Bacillus subtilis

1346 CAS15, has a biocontrol effect on Fusarium wilt and promotes the growth of pepper. European 1347 Journal of Soil Biology 47:138-145 https://doi.org/10.1016/j.ejsobi.2010.11.001

1348 Yusuf M, Fariduddin Q, Hayat S, Ahmad A. 2011. Nickel: an overview of uptake, essentiality 1349 and toxicity in plants. Bulletin of Environmental Contamination and Toxicology 86:1-17 1350 https://doi.org/10.1007/s00128-010-0171-1

1351 Zaid A, Mohammad FS, Wani SH, Siddique KMN. 2019. Salicylic acid enhances nickel stress 1352 tolerance by up-regulating antioxidant defense and glyoxalase systems in mustard plants. 
1353 Ecotoxicology and Environmental Safety 180:575-587

1354 https://doi.org/10.1016/j.ecoenv.2019.05.042

1355 Zaidi S, Usmani S, Singh BR, Musarrat J. 2006. Significance of Bacillus subtilis strain SJ-101 as 1356 a bioinoculant for concurrent plant growth promotion and nickel accumulation in Brassica 1357 juncea. Chemosphere 64(6):991-997 https://doi.org/10.1016/j.chemosphere.2005.12.057 1358 Zahra S, Mahmood S, Noreen S, Akrem A. 2018. Independent and combined nickel and 1359 cadmium induced lipid peroxidation of biological membranes and its mitigation through 1360 antioxidant enzymes in Grewia asiatica L. Pakistan Journal of Life and Social Sciences 1361 16(1):48-54 http://www.pjlss.edu.pk/pdf_files/2018_1/48-54.pdf

1362 Zhang H, Zhang L, Li J, Chen M, An R-D. 2020. Comparative study on the bioaccumulation of 1363 lead, cadmium and nickel and their toxic effects on the growth and enzyme defense strategies of 1364 a heavy metal accumulator, Hydrilla verticillata (L.f.) Royle. Environmental Science and 1365 Pollution Research 27:9853-9865 https://doi.org/10.1007/s11356-019-06968-0

1366 Zhao J, Lu C, Tariq M, Xiao Q, Zhang W, Huang K, Lu Q, Lin K, Liu Z. 2019. The response 1367 and tolerance mechanisms of lettuce (Lactuca sativa L.) exposed to nickel in a spiked soil 1368 system. Chemosphere.222:399-406 https://doi.org/10.1016/j.chemosphere.2019.01.119 1369 Zhao Y, Xing L, Wang X, Hou Y-J, Gao J, Wang P, Duan CG, Zhu X, Zhu JK 2014. The ABA 1370 receptor PYL8 promotes lateral root growth by enhancing MYB77-dependent transcription of 1371 auxin-responsive genes. Science Signaling 7(328):ra53 https://doi.org/10.1126/scisignal.2005051 1372 1373 1374 
Figure 1

\section{Effects of PGPB on plants under Ni-stress}

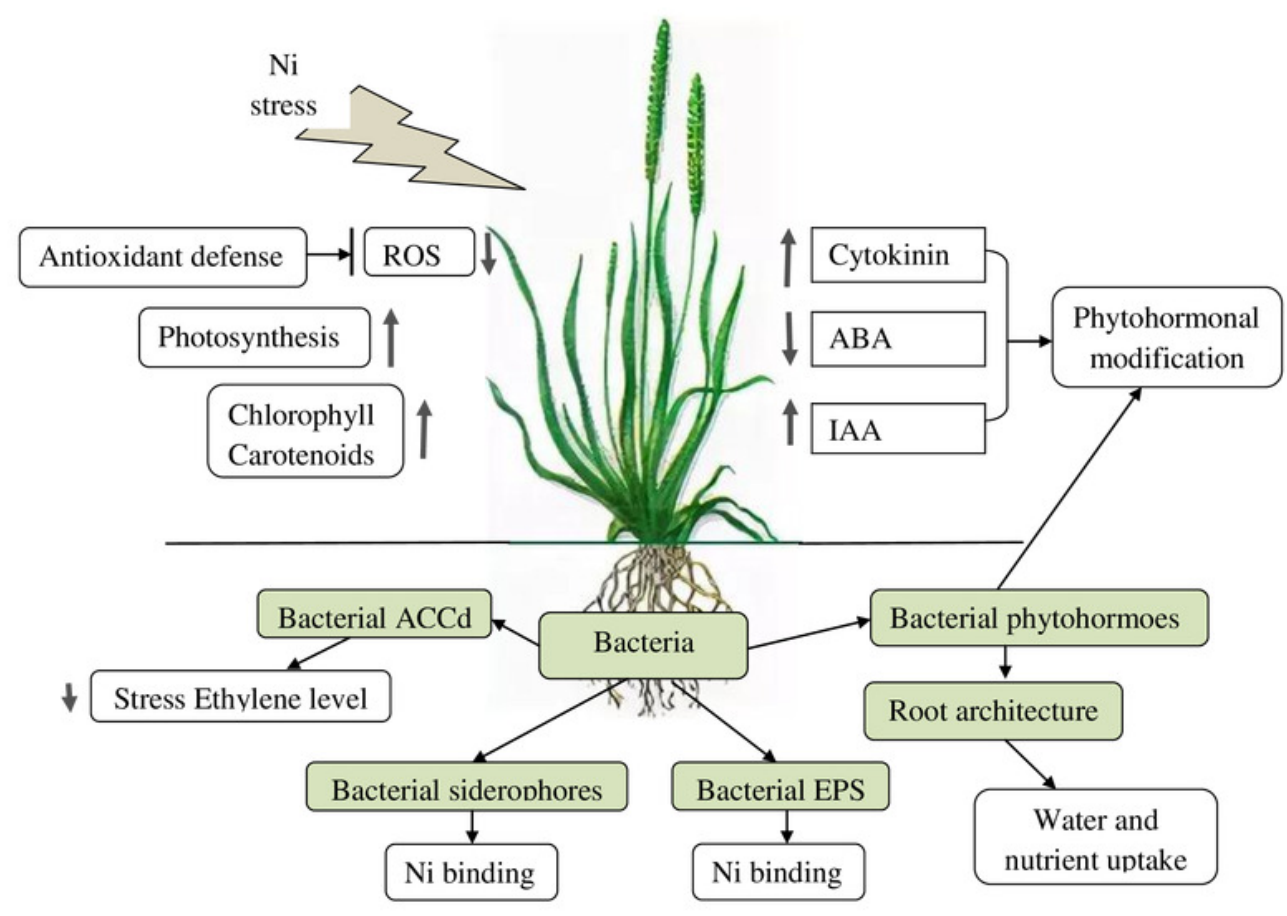




\section{Table $\mathbf{1}$ (on next page)}

Plants defense mechanisms under Ni stress.

Notes: (+) - increased, (-) - decreased; APX - ascorbate peroxidase, CAT - catalase, MDA malone dialdehyde, GSH-Px glutathione peroxidase, GST glutathione S-transferase activity, GR glutathione reductase, POD - peroxidase activity, SOD - superoxide dismutase 


\section{Table 1:}

2 Plants defense mechanisms under Ni stress.

\begin{tabular}{|c|c|c|c|}
\hline Plant species & Ni conc. & Mechanisms & Reference \\
\hline \multirow[b]{2}{*}{$\begin{array}{l}\text { Triticum } \\
\text { aestivum } \mathrm{L} .\end{array}$} & $25-50 \mu \mathrm{g} / \mathrm{L}$ & $(+)$ SOD activity, proline content & \multirow[b]{2}{*}{$\begin{array}{l}\text { Gajewska et al., } \\
\text { 2006; Parlak, } 2016\end{array}$} \\
\hline & $200 \mu \mathrm{M}$ & $\begin{array}{l}(+) \text { proline content in shoots; POD, GST } \\
\text { activities } \\
(-) \text { SOD, CAT activities }\end{array}$ & \\
\hline $\begin{array}{l}\text { Atropa } \\
\text { belladonna } \mathrm{L} .\end{array}$ & $50-200 \mu \mathrm{M}$ & $\begin{array}{l}(+) \text { proline, spermine, spermidine contents } \\
(-) \text { content of putrescine }\end{array}$ & $\begin{array}{l}\text { Stetsenko et al., } \\
2011\end{array}$ \\
\hline $\begin{array}{l}\text { Solanum } \\
\text { nigrum L }\end{array}$ & $100 \mu \mathrm{M}$ & $\begin{array}{l}\text { (+) SOD and CAT activities in roots } \\
(+) \text { SOD and APX activities in shoots } \\
\text { (-) CAT activity in shoots }\end{array}$ & Soares et al., 2016 \\
\hline \multirow[b]{2}{*}{$\begin{array}{l}\text { Oryza } \\
\text { sativa } \mathrm{L} .\end{array}$} & $10-50 \mu \mathrm{M}$ & (-) MDA concentrations & \multirow[b]{2}{*}{ Rizwan et al., 2017} \\
\hline & $100-200 \mu \mathrm{M}$ & $\begin{array}{l}(+) \text { proline content; POD and CAT activities } \\
\text { in roots and shoots } \\
(-) \text { SOD activity in roots and shoots }\end{array}$ & \\
\hline $\begin{array}{l}\text { Lactuca } \\
\text { sativa } \mathrm{L} .\end{array}$ & $\begin{array}{l}400-600 \mathrm{mg} / \mathrm{kg} \text { of } \\
\text { soil }\end{array}$ & $\begin{array}{l}\text { (+) CAT, POD, SOD activities in shoots } \\
(+) \text { MDA and GST levels }\end{array}$ & Zhao et al., 2019 \\
\hline $\begin{array}{l}\text { Alyssum } \\
\text { inflatum Nyár. }\end{array}$ & $100-400 \mu \mathrm{M}$ & $\begin{array}{l}\text { (+) proline content; } \\
(+) \text { SOD, POD, CAT, APX activities }\end{array}$ & $\begin{array}{l}\text { Najafi, Karimi \& } \\
\text { Ghasempour, } 2019\end{array}$ \\
\hline \multirow{2}{*}{$\begin{array}{l}\text { Hydrilla } \\
\text { verticillata } \\
\text { (Lf) Royle }\end{array}$} & $5-15 \mu \mathrm{M}$ & $\begin{array}{l}\text { (+) SOD and CAT activities in leaves and } \\
\text { stems; POD activity in leaves } \\
(-) \text { POD activity in stems }\end{array}$ & \multirow{2}{*}{$\begin{array}{l}\text { Song et al., 2018; } \\
\text { Zhang et al., } 2020\end{array}$} \\
\hline & $20-40 \mu \mathrm{M}$ & $\begin{array}{l}\text { (-) SOD and CAT activities in leaves and } \\
\text { stems; POD activity in leaves } \\
(+) \text { POD activity in stems }\end{array}$ & \\
\hline Vigna mungo L. & $10-100 \mu \mathrm{M}$ & $(+)$ proline content & Singh et al., 2012 \\
\hline $\begin{array}{l}V . \text { cylindrical L., } \\
V . \text { radiate L. }\end{array}$ & $50-150 \mu \mathrm{M}$ & $(+) \mathrm{SOD}, \mathrm{CAT}$ and POD activities in roots & $\begin{array}{l}\text { Mahmood et al., } \\
2016\end{array}$ \\
\hline Populus nigra L. & $200-800 \mu \mathrm{M}$ & $(+)$ CAT and APX activities in leaves & Kulac et al., 2018 \\
\hline $\begin{array}{l}\text { Pisum } \\
\text { sativum L. }\end{array}$ & $100 \mu \mathrm{M}$ & $\begin{array}{l}\text { (+) SOD, POD, CAT, APX, GSH-Px, GR } \\
\text { activities, proline, glycinebetaine contents }\end{array}$ & Balal et al., 2016 \\
\hline \multirow{2}{*}{$\begin{array}{l}\text { Landoltia } \\
\text { punctate }\end{array}$} & $0.01-0.5 \mathrm{mg} / \mathrm{L}$ & $(+)$ SOD, POD, CAT activities & \multirow{2}{*}{ Guo et al., 2017} \\
\hline & $5-10 \mathrm{mg} / \mathrm{L}$ & (-) SOD, POD, CAT activities & \\
\hline \multirow{2}{*}{$\begin{array}{l}\text { Grewia } \\
\text { asiatica L. }\end{array}$} & $20 \mathrm{mg} / \mathrm{kg}$ of soil & (-) SOD, CAT, POD activities & \multirow[b]{2}{*}{ Zahra et al., 2018} \\
\hline & $\begin{array}{l}40-60 \mathrm{mg} / \mathrm{kg} \text { of } \\
\text { soil }\end{array}$ & $\begin{array}{l}\text { (+) POD activity } \\
(-) \text { SOD, CAT activities }\end{array}$ & \\
\hline Glycine $\max \mathrm{L}$. & $0.05-20 \mu \mathrm{M}$ & (+) SOD, POD activities & Reis et al., 2017 \\
\hline $\begin{array}{l}\text { Catharanthus } \\
\text { roseus L. }\end{array}$ & $2.5-50 \mathrm{mM}$ & $(+)$ proline content, CAT activity & $\begin{array}{l}\text { Arefifard, Mahdieh } \\
\text { \& Amirjani, } 2014\end{array}$ \\
\hline $\begin{array}{l}\text { Medicago } \\
\text { sativa } \mathrm{L} .\end{array}$ & $50-500 \mathrm{mg} / \mathrm{kg}$ & $(+)$ POD activity & Helaoui et al., 2020 \\
\hline $\begin{array}{l}\text { Avéna sativa L., } \\
\text { Panicum } \\
\text { miliaceum L. }\end{array}$ & $10-40 \mathrm{ppm}$ & $\begin{array}{l}(+) \text { proline content, POD and SOD activities } \\
\text { in roots and shoots } \\
(-) \text { CAT activity in roots and shoots }\end{array}$ & Gupta et al., 2017 \\
\hline $\begin{array}{l}\text { Amaranthus } \\
\text { paniculatus L. }\end{array}$ & $25-150 \mu \mathrm{M}$ & $\begin{array}{l}\text { (+) GSH-Px, SOD activities in leaves } \\
\text { (-) APX, CAT, GSH-Px, SOD activities in } \\
\text { roots }\end{array}$ & Pietrini et al., 2015 \\
\hline $\begin{array}{l}\text { Brassica } \\
\text { juncea } \mathrm{L} .\end{array}$ & $100-400 \mu \mathrm{M}$ & $\begin{array}{l}\text { (+) proline content, SOD activity } \\
\text { (-) APX, CAT activities }\end{array}$ & $\begin{array}{l}\text { Thakur \& Sharma, } \\
2016\end{array}$ \\
\hline
\end{tabular}

3

4 Notes: (+) - increased, (-) - decreased; APX - ascorbate peroxidase, CAT - catalase, MDA - 
5 malone dialdehyde, GSH-Px glutathione peroxidase, GST glutathione S-transferase activity, GR

6 glutathione reductase, POD - peroxidase activity, SOD - superoxide dismutase 


\section{Table 2 (on next page)}

Effect of PGPB on plants under Ni stress.

Notes: ACC deaminase - 1-aminocyclopropane-1-carboxylic acid deaminase, IAA - indole-3acetic acid, SOD - superoxide dismutase, CAT - catalase, POD - peroxidase activity, APX ascorbate peroxidase, GR - glutathione reductase. 
Table 2:

2 Effect of PGPB on plants under Ni stress.

\begin{tabular}{|c|c|c|c|}
\hline Plant species & Bacteria & Effect & References \\
\hline Brassica campestris L. & Kluyvera ascorbata SUD165 & $\begin{array}{l}\text { Bacterium displayed ACC deaminase activity, and produced } \\
\text { siderophores, and decreased the level of stress ethylene induced by the } \mathrm{Ni}\end{array}$ & $\begin{array}{l}\text { Burd, Dixon \& } \\
\text { Glick, } 1998\end{array}$ \\
\hline Brassica juncea L. & Bacillus subtilis SJ-101 & Bacterium produced IAA and stimulated of Ni-phytoextraction & $\begin{array}{l}\text { Zaudi et al., } \\
2006\end{array}$ \\
\hline Brassica juncea $\mathrm{L}$. & $\begin{array}{l}\text { Psychrobacter sp. SRA1, } \\
\text { Bacillus cereus SRA10 }\end{array}$ & $\begin{array}{l}\text { Bacteria displayed ACC deaminase activity, produced a siderophores and } \\
\text { IAA, increased the accumulation of } \mathrm{Ni} \text { in the root and shoot tissues }\end{array}$ & \multirow{2}{*}{$\begin{array}{l}\text { Ma, Rajkumar } \\
\& \text { Freitas, } 2009\end{array}$} \\
\hline $\begin{array}{l}\text { Brassica juncea L.; } \\
\text { Brassica oxyrrhina Coss }\end{array}$ & Psychrobacter sp. SRA2 & $\begin{array}{l}\text { Bacterium displayed ACC deaminase activity, produced a siderophores } \\
\text { and IAA, increased the fresh and dry biomass of the plants }\end{array}$ & \\
\hline $\begin{array}{l}\text { Brassica juncea } \mathrm{L} . ; \\
\text { Ricinus communis L. }\end{array}$ & $\begin{array}{l}\text { Pseudomonas sp. A3R3, } \\
\text { Psychrobacter } \text { sp. SRS8 }\end{array}$ & $\begin{array}{l}\text { Bacteria improved plant biomass production and decreased heavy metal } \\
\text { accumulation }\end{array}$ & Ma et al., 2015 \\
\hline $\begin{array}{l}\text { Brassica juncea L.; } \\
\text { Luffa cylindrical L.; } \\
\text { Sorghum halepense L. }\end{array}$ & Bacillus megaterium SR28C & $\begin{array}{l}\text { Bacterium alleviated the detrimental effects of Ni by reducing its uptake } \\
\text { and translocation to the plants }\end{array}$ & $\begin{array}{l}\text { Rajkumar, Ma } \\
\text { \& Freitas, } 2013\end{array}$ \\
\hline Vigna unguiculata $\mathrm{L}$. & Streptomyces acidiscabies E13 & $\begin{array}{l}\text { Bacterium produced hydroxamate siderophores and promoted plant } \\
\text { growth under Fe- and Ni- stress }\end{array}$ & $\begin{array}{l}\text { Dimpka et al., } \\
2008\end{array}$ \\
\hline Vinca rosea $\mathrm{L}$. & Bacillus megaterium MCR-8 & $\begin{array}{l}\text { Bacterium alleviated Ni stress, increased the accumulation of total } \\
\text { phenols, flavonoids and enzymes SOD, CAT, POD, APX, improved } \\
\text { phytoextraction }\end{array}$ & $\begin{array}{l}\text { Khan et al., } \\
2017\end{array}$ \\
\hline Oryza sativa L. & $\begin{array}{l}\text { Enterobacter ludwigii SAK5, } \\
\text { Exiguobacterium indicum SA22 }\end{array}$ & $\begin{array}{l}\text { Bacteria increased plant growth parameters under } \mathrm{Cd} \text { and Ni stress, also } \\
\text { enhance glutathione, proline, and sugar content }\end{array}$ & Jan et al., 2019 \\
\hline Cicer arietinum $\mathrm{L}$. & Pseudomonas aeruginosa SFP1 & $\begin{array}{l}\text { Bacterium declined the level of stress markers (proline and APX, SOD, } \\
\text { CAT, and GR), as well as with Cr (VI) and Ni uptake by plants }\end{array}$ & $\begin{array}{l}\text { Saif \& Khan, } \\
2018\end{array}$ \\
\hline Rafanus sativus L. & Bacillus sp. CIK-516 & $\begin{array}{l}\text { Bacterium produced IAA, and displayed ACC deaminase activity, and } \\
\text { increased Ni uptake by radish }\end{array}$ & $\begin{array}{l}\text { Akhtar et al., } \\
2018\end{array}$ \\
\hline Triticum aestivum & Bacillus subtilis BM2 & $\begin{array}{l}\text { Bacterium displayed ACC deaminase activity, produced IAA, } \\
\text { siderophores, ammonia. Bacterium increased plant growth parameters } \\
\text { under Ni stress, decreased Ni content in plants and decrease SOD, GR } \\
\text { and CAT activity }\end{array}$ & $\begin{array}{l}\text { Rizvi et al., } \\
2019\end{array}$ \\
\hline
\end{tabular}

3 Notes: ACC deaminase - 1-aminocyclopropane-1-carboxylic acid deaminase, IAA - indole-3-acetic acid, SOD - superoxide

4 dismutase, CAT - catalase, POD - peroxidase activity, APX - ascorbate peroxidase, GR - glutathione reductase. 